\title{
Tumor-Associated Macrophages in Pancreatic Ductal Adenocarcinoma: Therapeutic Opportunities and Clinical Challenges
}

\author{
Ashleigh R. Poh *(i) and Matthias Ernst
}

check for updates

Citation: Poh, A.R.; Ernst, M.

Tumor-Associated Macrophages in Pancreatic Ductal Adenocarcinoma: Therapeutic Opportunities and Clinical Challenges. Cancers 2021, 13, 2860. https://doi.org/10.3390/ cancers 13122860

Academic Editor: Rolf A. Brekken

Received: 30 April 2021

Accepted: 6 June 2021

Published: 8 June 2021

Publisher's Note: MDPI stays neutral with regard to jurisdictional claims in published maps and institutional affiliations.

Copyright: (c) 2021 by the authors. Licensee MDPI, Basel, Switzerland. This article is an open access article distributed under the terms and conditions of the Creative Commons Attribution (CC BY) license (https:/ / creativecommons.org/licenses/by/ $4.0 /)$.
Olivia Newton-John Cancer Research Institute and La Trobe University School of Cancer Medicine, Heidelberg, VIC 3084, Australia; Matthias.Ernst@onjcri.org.au

* Correspondence: ashleigh.poh@onjcri.org.au

Simple Summary: Macrophages are a major component of the pancreatic tumor microenvironment, and their increased abundance is associated with poor patient survival. Given the multi-faceted role of macrophages in promoting pancreatic tumor development and progression, these cells represent promising targets for anti-cancer therapy.

Abstract: Pancreatic ductal adenocarcinoma (PDAC) is an aggressive malignant disease with a 5-year survival rate of less than $10 \%$. Macrophages are one of the earliest infiltrating cells in the pancreatic tumor microenvironment, and are associated with an increased risk of disease progression, recurrence, metastasis, and shorter overall survival. Pre-clinical studies have demonstrated an unequivocal role of macrophages in PDAC by contributing to chronic inflammation, cancer cell stemness, desmoplasia, immune suppression, angiogenesis, invasion, metastasis, and drug resistance. Several macrophagetargeting therapies have also been investigated in pre-clinical models, and include macrophage depletion, inhibiting macrophage recruitment, and macrophage reprogramming. However, the effectiveness of these drugs in pre-clinical models has not always translated into clinical trials. In this review, we discuss the molecular mechanisms that underpin macrophage heterogeneity within the pancreatic tumor microenvironment, and examine the contribution of macrophages at various stages of PDAC progression. We also provide a comprehensive update of macrophage-targeting therapies that are currently undergoing clinical evaluation, and discuss clinical challenges associated with these treatment modalities in human PDAC patients.

Keywords: pancreatic ductal adenocarcinoma; tumor microenvironment; macrophages; tumor immunology; immunotherapy

\section{Introduction}

Pancreatic ductal adenocarcinoma (PDAC) is an aggressive malignant disease with a 5-year survival rate of less than $10 \%$ and is the seventh leading cause of cancer-related death worldwide [1,2]. In contrast to other cancer types, the survival rate of PDAC patients has not improved substantially over the past 40 years [3,4]. Two chemotherapy combinations, Gemcitabine/nab-Paclitaxel and FOLFIRINOX (irinotecan, oxaliplatin, 5-fluororacil and leucovorin), are currently used to treat PDAC; however, response to either of these two regimens is only observed in up to $30 \%$ of patients [4-6]. While surgery offers a potential cure, less than $20 \%$ of cases are resectable at diagnosis and most patients that undergo surgery still die of the disease due to local recurrence and/or metastasis [7-9]. Thus, there is an unmet clinical need to improve survival outcomes for PDAC patients.

A hallmark of PDAC is the presence of a dense desmoplastic (fibrotic) reaction that surrounds cancer cells and can account for up to $80 \%$ of the tumor mass [10]. It is comprised of a heterogeneous population of cells (e.g., fibroblasts, stellate cells, immune cells, endothelial cells), acellular components (e.g., fibrin, collagen, hyaluronic acid, fibronectin, 
growth factors, cytokines), and is characterized by biophysical features (e.g., low $\mathrm{pH}$, hypoxia, high interstitial pressure) that interact to promote tumor growth and limit therapeutic response [11]. For example, the presence of a dense extracellular matrix and high interstitial fluid pressure within the stroma limits the delivery and distribution of anticancer drugs [12]. Meanwhile, immunosuppressive factors secreted by cancer-associated fibroblasts and myeloid cells enables immune escape by preventing the infiltration and activation of cytotoxic effector cells [13]. Due to the functional complexity of the PDAC tumor microenvironment, complementary stromal- and immune-targeted treatment strategies that can deconstruct the desmoplastic stroma and reduce immunosuppression may offer a rational treatment approach to improve therapy response in PDAC.

Tumor-associated macrophages (TAMs) are one of the earliest infiltrating cells in pancreatic intraepithelial neoplasms and continue to increase during progression to invasive cancer $[14,15]$. Macrophage density is an independent prognostic factor in human PDAC patients and is associated with a higher risk of disease progression, recurrence, metastasis, and shorter overall survival [16]. Meanwhile, pre-clinical PDAC mouse models have provided unequivocal evidence for the importance of these cells in driving angiogenesis, matrix remodeling, immunosuppression, tumor cell invasion, and drug resistance [17-21]. In this review, we will delineate the contribution of TAMs in PDAC, and explore how they may be utilized as therapeutic targets.

\section{Origin of Macrophages in PDAC}

Macrophages in PDAC are derived from a mixed population of tissue-resident cells and circulating monocytes. Tissue-resident macrophages are diverse in their ontogeny and arise from embryonic precursors or from adult hematopoietic stem cell (HSC) progenitors. Monocyte-derived cells also contribute to the macrophage population in PDAC and are recruited into tissues by chemotactic signals [17,21-23] (Figure 1). Strikingly, loss of monocyte-derived macrophages has limited effects on PDAC progression, while depletion of tissue-resident macrophages significantly impairs tumor growth [17]. These results suggest that tissue-resident macrophages are more potent drivers of PDAC compared to their monocyte-derived counterparts, and are indispensable for tumor development.

Although the gene expression profile of embryonic- and HSC-derived macrophages are similar under normal homeostatic conditions, they exhibit distinct transcriptional profiles and ex vivo functions in PDAC (Figure 1). During tumor development, embryonicallyderived macrophages undergo significant expansion in situ and proliferate at higher rates compared to their HSC-derived counterparts [17]. They also exhibit a pro-fibrotic transcriptional profile and produce significantly more collagen compared to HSC-derived TAMs, which suggests their involvement in 'fine-tuning' fibrotic responses [17,21-23]. In contrast, HSC/monocyte-derived macrophages have well-recognized roles in antigen presentation, immunosuppression, and therapeutic resistance [17-21]. While these findings suggest that embryonic- and HSC/monocyte-derived macrophages have distinct and non-redundant roles, other subsets derived from these two tissue origins are expected given the importance of microenvironmental cues in shaping macrophage plasticity. 


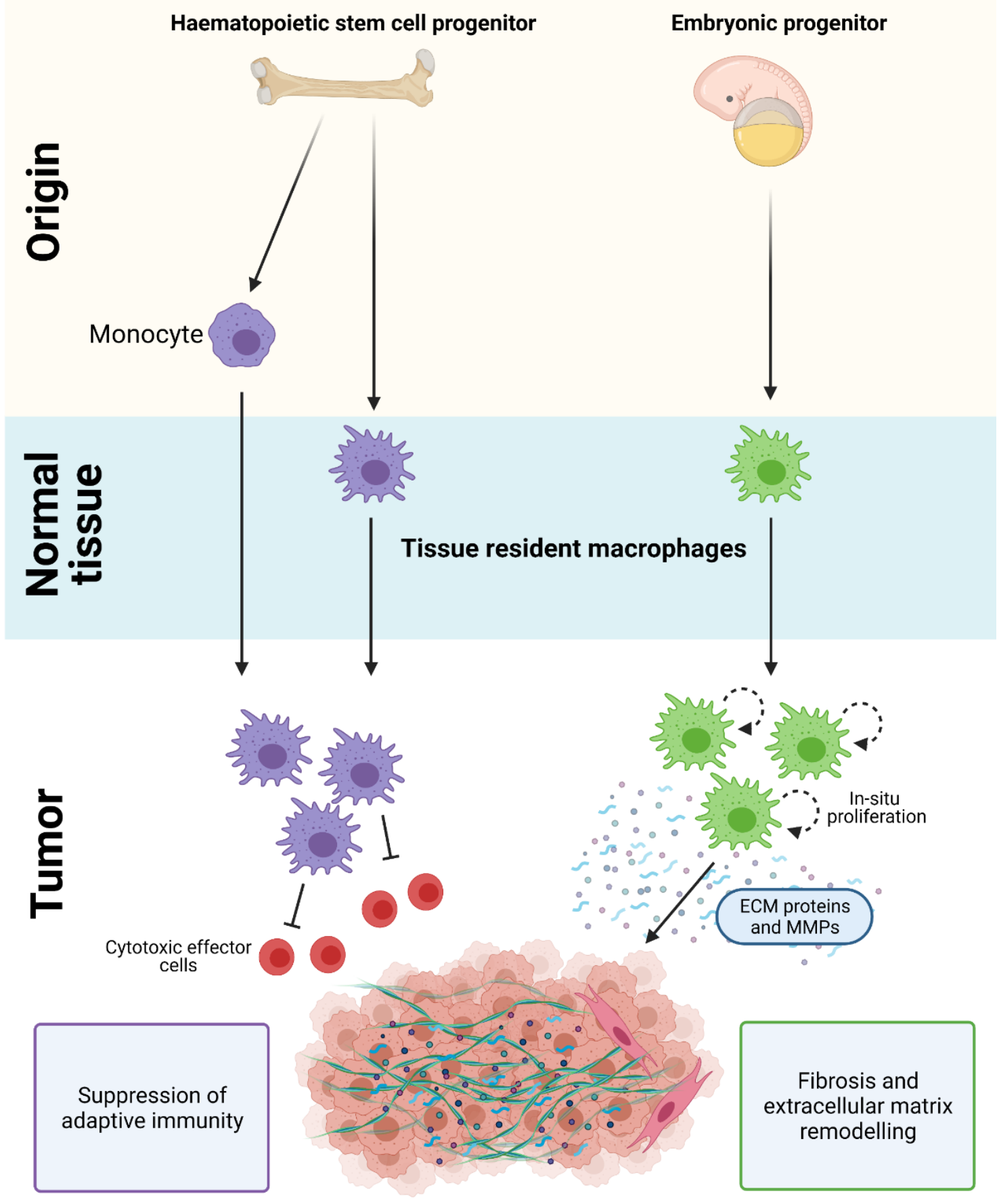

Figure 1. Origin of macrophages in PDAC. Macrophages in PDAC are derived from a mixed population of tissue-resident cells and circulating monocytes. HSC/monocyte-derived macrophages play a key role in regulating immune suppression and adaptive immunity, while embryonically-derived macrophages are important in promoting fibrosis and extracellular matrix remodeling in PDAC. Figure created in Biorender.

\section{Macrophage Polarization}

In addition to cellular ontogeny, macrophage heterogeneity is also influenced by nichespecific signaling events that occur within the tumor microenvironment. Macrophages are able to reversibly alter their phenotype in response to environmental cues, which include stimuli derived from pathogens, stromal and immune cells, as well as the extracellular matrix and metabolites [24]. In turn, this enables macrophages to perform a variety of 
different activities, including host defense, clearance of cellular debris, stimulating adaptive immunity, and wound healing.

Most of our knowledge on macrophage polarization has relied on in vitro techniques, including the stimulation of naïve M0 macrophages with polarizing cytokines. Differences in transcriptional profiles, cell-surface markers, signaling pathways and biological functions have subsequently been used to distinguish various activation states, which are broadly divided into either 'classically-activated M1' (CAM) or 'alternatively-activated M2' (AAM) subtypes [24-27] (Figure 2). However, while the 'M0 to M1/M2' classification system represents a useful and simplified conceptual framework, this linear model does not reflect the true complexity of macrophage polarization in an in vivo tumor setting. Instead, macrophage polarization should be viewed as a highly dynamic and reversible process where TAMs exist on continuum of diverse functional states, and can encompass features of both 'M1/M2' phenotypes.

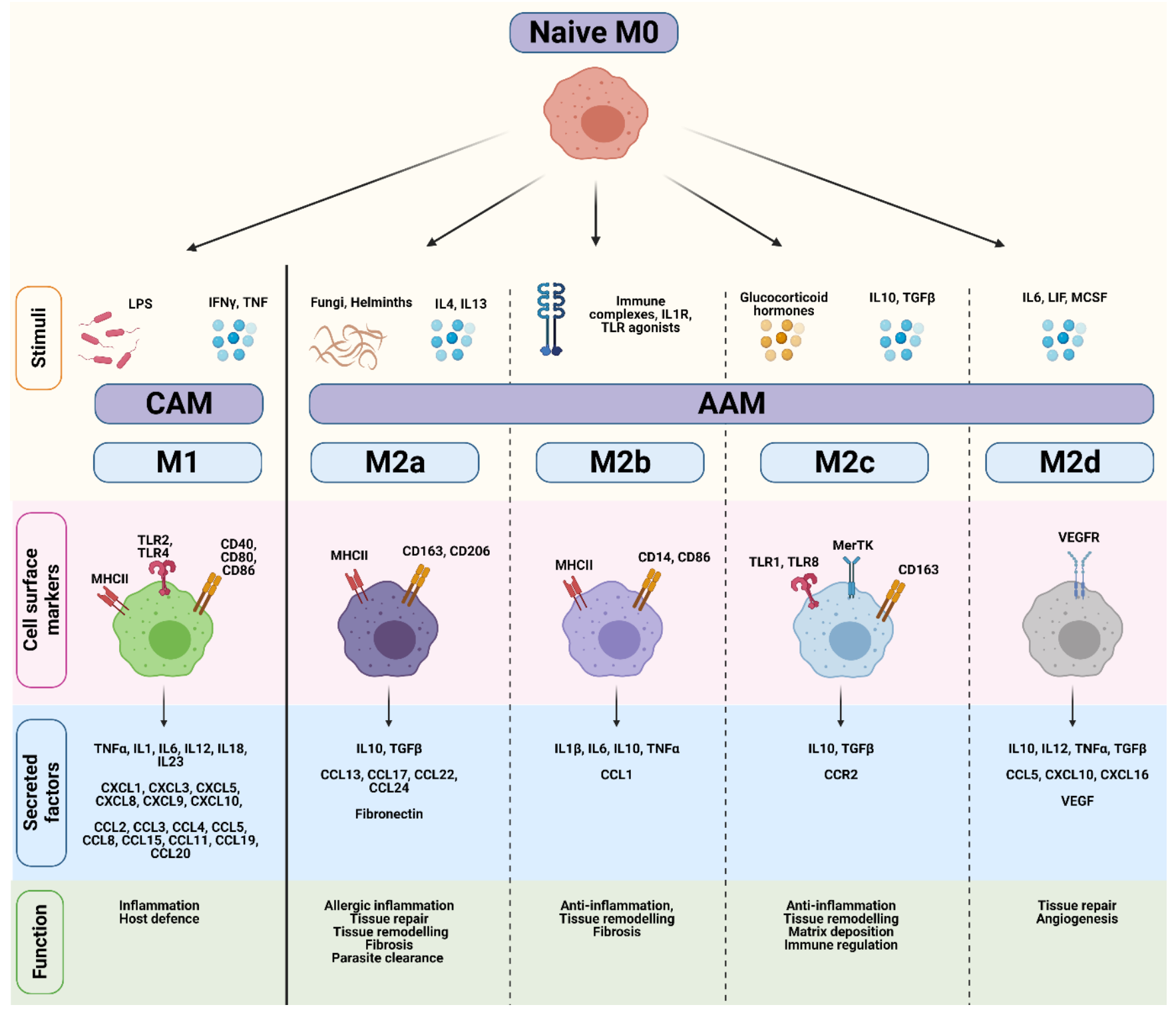

Figure 2. Comparison of CAM and AAM macrophage endotypes. Naïve M0 macrophages differentiate into classicallyactivated M1 (CAM) or alternatively-activated M2 (AAM) subtypes in response to various stimuli. CAMs and AAMs exhibit distinct surface markers, cytokines, and biological functions. Figure created in Biorender. 
Classically-activated M1 macrophages are induced in response to bacterial lipopolysaccharide (LPS), or the Th1 cytokines IFN $\gamma$ and TNF $\alpha$ (Figure 2) [26,28]. IFN $\gamma$ and TNF $\alpha$ are produced by antigen-presenting cells upon recognition of pathogenic signals, but can also be secreted by T-cells and natural killer (NK) cells. Once activated, CAMs secrete pro-inflammatory cytokines (e.g., TNF $\alpha$, IL1 $\beta$, IL12), effector molecules (e.g., reactive nitrogen intermediates), and chemokines (e.g., CXCL9, CXCL10) to amplify and sustain their anti-microbial and tumoricidal activity [24]. Although these cytokines play an important role in host defense, sustained production of these molecules may result in chronic inflammation. A fine-tuned balance is therefore necessary to maintain homeostasis and prevent extensive tissue damage.

Alternatively-activated M2 macrophages play a pivotal role in wound healing and suppression/regulation of inflammatory responses. They are divided into at least four distinct subtypes (M2a, M2b, M2c, and M2d) based on their functional differences in response to different stimuli [25,29] (Figure 2). M2a macrophages are induced by IL4, IL13, and helminth and parasitic infections. They secrete high levels of immunosuppressive cytokines (e.g., IL10, TGF $\beta$ ), chemokines (e.g., CCL13, CCL17), and components of the extracellular matrix to promote tissue repair, remodeling, and fibrosis. Common markers used to identify M2a macrophages include mannose receptor (CD206) and scavenger receptors such as CD163 [30]. M2b macrophages are induced by immune complexes and TLR agonists, and regulate immune responses through the production of pro-inflammatory (e.g., IL1 $\beta$, IL6, TNF $\alpha$ ) and anti-inflammatory cytokines (e.g., IL10) [31]. M2c macrophages are induced following stimulation with IL10, TGF $\beta$, and glucocorticoids, and highly express Mer receptor tyrosine kinase (MerTK) which enables efficient phagocytosis of apoptotic cells [32]. Lastly, M2d macrophages are induced by IL6, and mediate tissue repair and angiogenesis through secretion of IL10 and VEGF $[33,34]$. Thus, AAMs encompass a functionally diverse group of cells that contribute to immunosuppression, tissue remodeling, and angiogenesis.

\section{Role of TAMs in PDAC}

Although macrophages play a central role in host defense, inappropriate or prolonged activation can result in immune dysregulation, tissue damage, and disease [35]. Depending on their polarization, macrophages can play contrasting roles in tumor development and progression. For example, newly tumor-infiltrated naïve M0 macrophages exert antitumorigenic activities via TNF $\alpha$ secretion [36]. However, their subsequent differentiation into AAMs reduces TNF $\alpha$ levels and suppresses their cytotoxic activity [36].

Pre-clinical PDAC mouse models have provided unequivocal evidence for the importance of TAMs in tumor development and progression. Genetic ablation of macrophages blocks the progression of precancerous lesions to adenocarcinomas, and reduces tumor formation in mice [37,38]. Meanwhile, pharmacological depletion of TAMs impairs angiogenesis [39,40], tumor cell invasion [41-44], and metastasis [20,39]. These findings suggest that there is a fine-tuned balance between the tumoricidal and tumor-promoting functions of TAMs. To date, the tumor-promoting roles of macrophages in PDAC that have been well characterized include chronic inflammation, promoting cancer stemness, desmoplasia, immune suppression, angiogenesis, invasion, metastasis, and drug resistance (Figure 3).

\subsection{Inflammation and Cancer Initiation}

Chronic inflammation is a key mediator of early PDAC development, and promotes malignant progression and metastatic spread to distant organs [45,46]. Risk factors for PDAC that promote systemic inflammation include chronic pancreatitis [47,48], obesity [49], tobacco smoking [50], and alcohol use [51]. During acute pancreatitis, macrophages are predominantly skewed towards a classically-activated endotype that produce high levels of TNF $\alpha$ and IL1 $\beta$ [52-54]. In contrast, AAMs are the dominant subtype observed in chronic pancreatitis, and interact with pancreatic stellate cells to accelerate fibrosis [55]. 

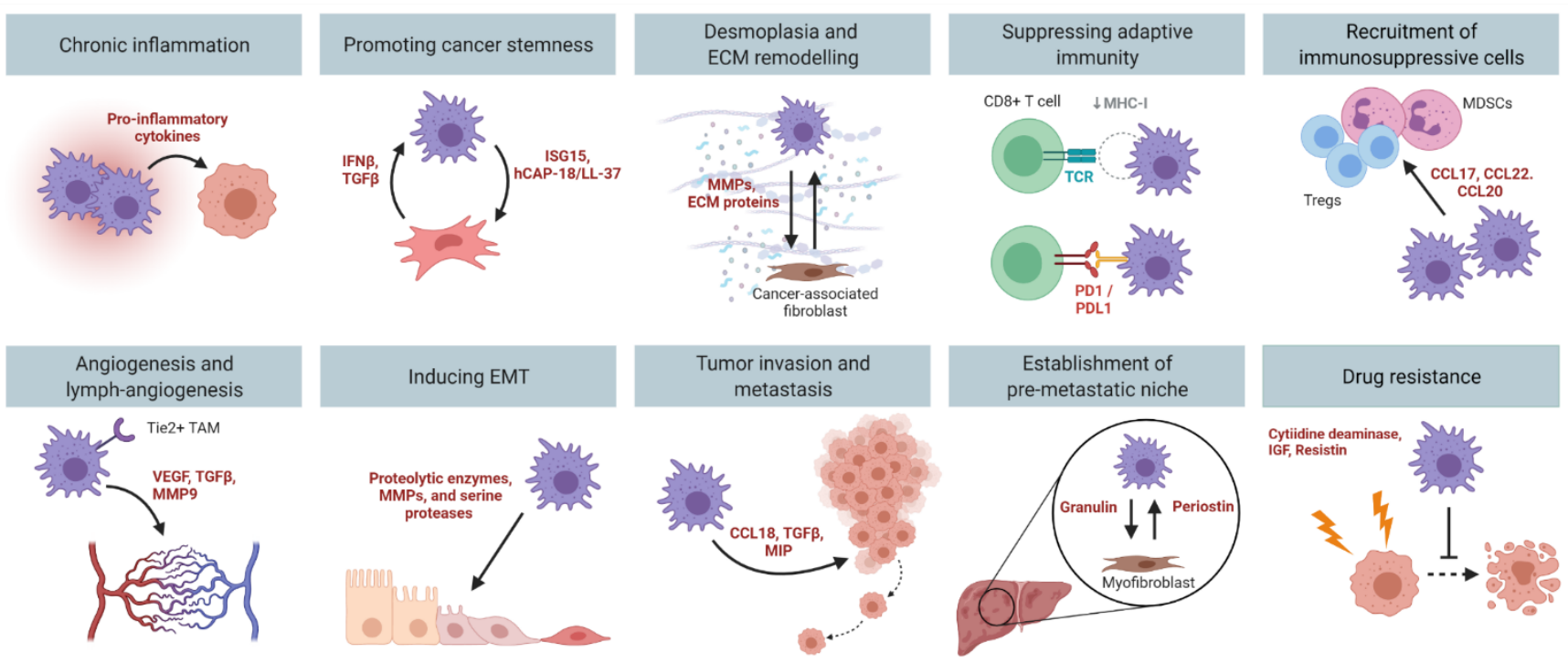

Figure 3. The multi-faceted role of TAMs in PDAC. Macrophages promote PDAC development and progression by contributing to chronic inflammation, promoting cancer stemness, desmoplasia, immune suppression, angiogenesis, inducing EMT, tumor invasion and metastasis, and mediating drug resistance. Figure created in Biorender.

In response to chronic inflammation, acinar pancreatic cells can adopt a metaplastic duct-like phenotype in a process known as acinar-to-ductal metaplasia (ADM) [56]. These precancerous lesions are frequently observed in pancreatitis [57], and may develop into pancreatic intraepithelial neoplasia (PanIN) following the acquisition of additional mutations such as oncogenic KRas [56,58]. Both ADM and PanIN are indispensable events in PDAC, and are marked by the progressive infiltration of macrophages that persist throughout tumor development $[37,59,60]$. Accordingly, macrophage depletion blocks the progression of ADM to PanIN, and reduces PDAC formation in mice [37,38].

Classically-activated M1 macrophages initiate ADM via the secretion of inflammatory mediators, including IL6 [61], TNF $\alpha$, and RANTES [37,62]. IL6 contributes to ADM through activation of JAK-STAT3 signaling [61], while TNF $\alpha$ and RANTES activate NFKB in acinar cells to drive proliferation, survival, and extracellular matrix degradation [37,62]. In turn, acinar cells express intercellular adhesion molecule-1 (ICAM-1), which induces a paracrine loop that sustains local inflammation and ADM transformation [38]. TAMs can also enhance the expression of heparin-binding epidermal growth factor-like growth factor (EGFR ligand) in pre-neoplastic lesions to facilitate ADM and the development of PanIN lesions [63]. Once ADM progresses to PanIN, inflammatory macrophages are reprogrammed towards an alternatively-activated endotype in response to IL13 secreted by neoplastic cells, and drive fibrosis via IL1Ra and CCR2 signaling [64].

Although additional inflammatory insults and genetic alterations are needed to drive the progression of PanIN to PDAC [65,66], neoplastic cells from PanIN lesions can undergo epithelial-to-mesenchymal transition (EMT), circulate in the blood, and seed in the liver before primary tumor development $[67,68]$. EMT occurs when tumor cells lose their intrinsic polarity and instead acquire a motile mesenchymal cell phenotype [69]. Features of EMT and epithelial cell invasion are most abundant at inflammatory foci of PanIN, and circulating pancreatic cells can be detected during pancreatitis [67]. These data suggest that establishment of a metastatic niche may precede primary tumor development. Thus, inflammation caused by macrophages can promote PDAC progression by facilitating changes within the microenvironment at the primary site of neoplasia, and by enabling the invasion and dissemination of tumor cells into secondary organs. 


\subsection{Promoting Cancer Cell Stemness}

Pancreatic cancer stem cells (PCSCs) are a rare population of immortal tumor cells that can self-renew and generate a heterogeneous lineage of cancer cells. Thus, PCSCs represent a cell population uniquely responsible for tumor heterogeneity, and play a fundamental role in tumor development, progression, and chemoresistance [70,71]. Although PCSCs can remodel their surroundings to maintain their self-renewing and tumorigenic properties, the tumor microenvironment also provides cues to upregulate EMT and stemness in PCSCs. Indeed, TAMs provide pivotal signals to promote PCSC survival, and in turn, PCSCs deliver tumor-promoting cues to TAMs to further enhance tumorigenesis.

PCSC density positively correlates with abundance of TAMs in PDAC, and is associated with a reduced overall patient survival [72]. Targeting macrophage recruitment by blocking CCR2 or CSF1R signaling decreases the number of PCSCs, and improves response to chemotherapy [20]. TAMs directly enhance the tumor-initiating capacity of PCSCs by activating the transcription factor STAT3 in PCSCs, which facilitates macrophage-mediated suppression of CD8 T-cells [20]. Human PCSCs also secrete IFN $\beta$ to stimulate TAMs to produce the IFN-stimulated factor ISG15. Consequently, TAM-derived ISG15 reinforces the self-renewing, invasive capacity, and tumorigenic potential of PCSCs [73]. PCSCs are also a major source of the TGF $\beta$ superfamily members Nodal/Activin A and TGF $\beta 1$, which induce the polarization of AAMs. In turn, AAMs secrete the antimicrobial peptide hCAP18/LL-37, which binds to receptors on the surface of PCSCs to enhance PCSC self-renewal, invasion, and tumorigenesis [74]. Together, these studies suggest that the intricate cross-talk between PCSCs and TAMs is an important driver for tumor development in PDAC.

\subsection{Desmoplasia and ECM Remodeling}

Desmoplasia is a prominent pathological characteristic of PDAC, and acts as a biophysical alteration that promotes tumor development, angiogenesis, metastasis, and drug resistance [11]. The dense and fibrous desmoplastic tissue is comprised of both cellular (e.g., fibroblasts, immune cells) and non-cellular connective tissue components (e.g., collagen, fibronectin) [11].

Pancreatic stellate cells (PSCs) are resident cells that maintain normal tissue architecture through the synthesis of ECM proteins and matrix-degrading enzymes such as matrix metalloproteinases (MMPs) [75]. In response to pancreatic injury or chronic inflammation, PSCs transform into an active myofibroblast-like phenotype and express high levels of alpha-smooth muscle actin [76,77]. This transition is accompanied by (1) an increase in proliferation and migration, (2) excessive synthesis of ECM proteins, MMPs and their inhibitors, and (3) the secretion of growth factors and cytokines that act in an autocrine and paracrine manner to enhance early tumor formation [75-80].

Reciprocal interactions between cancer-associated fibroblasts and AAMs trigger and sustain the desmoplastic reaction in PDAC. Co-culture of monocytes with PSCs and fibroblasts induces the production of immunosuppressive cytokines (e.g., IL6, IL8, IL10, IL33, GM-CSF, M-CSF), which promote the polarization of AAMs [81-83]. In turn, AAMs secrete growth factors (e.g., TGF $\beta 1$, PDGF, FGF2, granulin), cytokines (e.g., TNF $\alpha$, IL1, IL6), and chemokines (e.g., CCL2) that directly activate fibroblasts and perpetuate a feedforward loop to sustain the desmoplastic reaction $[84,85]$. PI3K $\gamma$ signaling in macrophages also regulates the expression of platelet-derived growth factor-BB, which stimulates tumor cell chemotaxis and fibroblast production of collagen in vitro and in vivo [86]. Meanwhile, TAMs accumulate in hypoxic areas in response to HIF1 $\alpha$, and activate PSCs via CCL2 secretion [87]. Macrophages can also directly deposit and regulate the extracellular matrix via production of ECM-producing enzymes (e.g., hyaluronan synthases), and ECMremodeling molecules (e.g., lysyl oxidase, MMPs) $[17,55]$. Thus, TAMs play an integral role in PDAC desmoplasia both directly and indirectly through their interactions with PSCs and cancer-associated fibroblasts. 


\subsection{Immune Suppression}

Macrophages are critical regulators of T-cell immunosurveillance, and establish a site of immune privilege in PDAC by inhibiting the recruitment of T-cells into the tumors [23]. TAMs also suppress T-cell activation via several major mechanisms, including (1) depletion of metabolites required for T-cell proliferation, (2) inhibition of T-cell activation by production of anti-inflammatory factors, (3) upregulation of inhibitory receptors to block T-cell function, and (4) generation of reactive oxygen species. Metabolism of L-arginine and L-tryptophan by TAMs decreases the expression of the $\mathrm{CD} 3 \zeta$ chain on T-cells, and results in T-cell anergy and impaired proliferation [88-90]. Likewise, increased Arginase I production by AAMs interferes with T-cell metabolism and cytotoxicity [91].

TAMs also secrete anti-inflammatory/immunosuppressive cytokines (e.g., TGF $\beta$, PGE2) and chemokines (e.g., CCL7, CCL2), which promote T-cell exhaustion and establishes a self-propagating tumor-permissive microenvironment [92-95]. In addition, macrophagederived IL10 impairs NK cell proliferation [96,97], while TGF $\beta$ signaling in TAMs inhibits the cytolytic activity of NK cells in a contact-dependent manner [98].

TAMs can also upregulate the expression of ligands that bind to inhibitory receptors on the surface of T-cells to inhibit their activation, proliferation, and effector functions $[99,100]$. These include PDL1/PDL2 and CD80/CD86, which bind to PD1 and CTLA4, respectively on the surface of CD8 T-cells. Other ligands include Dectin1, which is highly expressed by macrophages in mouse and human PDAC [101]. Binding of Dectin1 to Galectin-9 on the surface of infiltrating immune cells and cancer cells results in tolerogenic macrophage programming and suppression of adaptive immune responses [101].

Numerous studies have established a role of TAMs in driving the polarization and expansion of immunosuppressive cell types into the PDAC microenvironment. NLRP3 signaling in macrophages drives the differentiation of CD4 T-cells into tumor-promoting Th2 cells, Th17 cells, and Tregs, while suppressing Th1 cell polarization and cytotoxic CD8 T-cell activation [102]. Macrophage-derived chemokines such as CCL17, CCL22, and CCL20 also induce the migration of Tregs into tumors [95], and promote the regulatory functions of these cells via IL10 and TGF $\beta$ signaling [103]. Thus, TAMs can suppress anti-tumor responses by preventing the recruitment and activation of cytotoxic effector cells, and by promoting the accumulation of Tregs into tumors.

\subsection{Angiogenesis and Lymph-Angiogenesis}

Tumors require angiogenesis to obtain nutritional support and oxygen. TAMs are highly abundant in hypoxic areas of PDAC, and are associated with increased blood vessel formation via production of VEGF [104-108]. Upregulation of VEGF expression in TAMs requires the oncogenic transcription factors $\mathrm{HIF} 1 \alpha, \mathrm{NF} \kappa \mathrm{B}$, and STAT3, which promote an angiogenic switch that enhances blood vessel formation and tumor growth [39]. In addition to their accumulation in primary tumors, VEGF-expressing TAMs are found in pre-metastatic niches where they promote tumor cell extravasation and vascular permeability [39]. Accordingly, macrophage depletion significantly impairs angiogenesis and reduces circulating levels of VEGF [39,40]. Macrophage-derived exosomes miR-155-5p and miR-221-5p can also promote angiogenesis in PDAC by suppressing expression of the transcription factor E2F2 in endothelial cells [108]. Moreover, pancreatic cancer cells produce cytokines such as IL35 to stimulate the angiogenic activity of TAMs via expression of CXCL1 and CXCL8, while inhibition of this interaction reduces TAM infiltration and microvessel formation [109]. A novel subset of TAMs expressing the tyrosine-protein kinase receptor TIE2 also exhibit enhanced pro-angiogenic activity in PDAC [110] via the binding of its receptor to angiopoietins to promote blood vessel formation [111,112]. Indeed, the abundance of TIE2 macrophages positively correlates with increased microvessel density and a greater risk of developing metastatic disease in PDAC [110].

TAMs also contribute to lymph-angiogenesis, which represents an important route of tumor cell dissemination to regional lymph nodes. In PDAC patients, high lymphatic density positively correlates with increased lymph node metastasis, and reduced overall 
patient survival $[113,114]$. Lymph-angiogenesis is dependent on the binding of VEGF-C (a ligand overexpressed by cancer cells) to its receptor VEGFR-3 (expressed on TAMs). The VEGF-C/VEGFR-3 axis can promote lymph-angiogenesis directly by activating lymphatic endothelial cells $[115,116]$, or indirectly by increasing the secretion of molecules that induce lymph-angiogenesis including VEGF and MMP9 [117-119]. Of note, the presence of TAMs at the invasive front of PDAC tumors is associated with a poor prognosis due to accelerated lymphatic metastasis $[120,121]$.

\subsection{Tumor Invasion and Metastasis}

Metastasis is a major cause of mortality in PDAC patients, and begins when tumor cells acquire the ability to invade and break through the basement membrane into the surrounding stroma, where they can then spread to distant organs such as the liver, lung, and peritoneum [122,123].

Macrophage-derived cytokines and chemokines including IL1 $\beta$ [124], CCL18 [125], and IL8 [126] can promote the epithelial-mesenchymal transition of pancreatic cancer cells through various signaling pathways, including PAR1 [127] and TLR4/IL10 activation [128]. Following co-culture with AAMs, pancreatic cancer cells demonstrate increased fibroblastic morphology, upregulated expression of mesenchymal markers Vimentin and Snail, alongside downregulation of the epithelial marker E-cadherin [128]. These changes are also associated with an increase in tumor cell proliferation, migration, and proteolytic activity [128]. In addition, TAMs secrete proteolytic enzymes, MMPs, and serine proteases, which are important components that mediate ECM degradation and cell-ECM interactions. For example, the macrophage pro-inflammatory chemokines CCL20 and MIP3 $\alpha$ bind to CCR6 on the surface of PDAC cells to upregulate MMP9 expression and tumor invasion [41-44]. Macrophage-derived CCL18 also enhances the invasive ability of pancreatic cancer cells by inducing VCAM-1 expression. Reciprocally, VCAM-1-induced lactate production by pancreatic cancer cells polarizes macrophages towards an alternatively-activated endotype, thus forming a regulatory feedback loop within the tumor microenvironment [129]. Of note, TAMs that are associated with a pro-metastatic phenotype exhibit a pronounced glycolytic signature, and inhibition of glycolysis in TAMs disrupts their ability to support angiogenesis, tumor-cell extravasation, and EMT [40].

Primary tumors are capable of 'priming' distant organs and directing the mobilization of macrophages to these sites before tumor cells arrive [130]. These primed sites are referred to as pre-metastatic niches, and are largely established by macrophages that serve as a 'landing guide' for the homing of circulating tumor cells [131,132]. For example, the selective uptake of PDAC-derived exosomes by resident liver macrophages results in the activation of fibrotic pathways and the establishment of a pro-inflammatory milieu that supports metastasis [133]. Mechanistically, exosome-derived macrophage migration inhibitor factor (MIF) induces the release of TGF $\beta$ by resident liver macrophages, which in turn promotes the deposition of fibronectin by hepatic stellate cells [133]. These dense fibronectin deposits promote the accumulation of bone-marrow derived macrophages in the liver, and results in the formation of a pre-metastatic niche [133].

Consistent with the role of macrophages in supporting metastasis, pharmacological depletion of TAMs in mice reduces the spread of PDAC cells to the liver, lung, and spleen $[20,39]$. Strikingly, this anti-metastatic effect was independent of the presence of a primary tumor, since reduced lung metastasis was also detected in macrophage-depleted mice after tail vein injection of pancreatic cancer cells [39]. Likewise, in an orthotopic model of PDAC, immunosuppressive CCR2 ${ }^{+}$macrophages were recruited to the liver during tumor progression where they established a metastatic niche [21]. Once in the liver, macrophages secrete granulin which activate resident hepatic stellate cells into myofibroblasts that secrete periostin, resulting in a fibrotic microenvironment that sustains metastatic spread [85]. Disruption of the CCR2/CCL2 signaling axis or genetic depletion of granulin inhibits macrophage recruitment and protects against liver metastasis [21,85]. 


\subsection{Drug Resistance/Modulating Treatment Response}

One of the biggest clinical challenges of treating PDAC patients is the poor response of tumors to therapy, including radiotherapy and chemotherapy [134]. The ability of macrophages to modulate drug resistance and treatment response in PDAC has been extensively demonstrated using in vivo mouse models. The induction of EMT in pancreatic cancer cells by TAMs makes PDAC more resistant to chemotherapy [135]. Following treatment with radiotherapy or chemotherapy, PDAC tumor cells release inflammatory molecules including the chemokine CCL2, which recruits inflammatory macrophages to promote tumor proliferation and vascularization [18,19]. Tumor-derived CCL2 inhibits the efficacy of ablative radiotherapy and FOLFIRINOX chemotherapy in mice, while selective blockade of CCL2 using neutralizing antibodies blocked macrophage recruitment and restored the sensitivity of PDAC tumors to radiotherapy and chemotherapy $[18,19]$. TAMs can also mediate gemcitabine resistance by upregulating cytidine deaminase in tumor cells, an enzyme that metabolizes gemcitabine following its transport into the cell. Accordingly, inhibition of TAMs using a CSF1-receptor antagonist augmented the effect of chemotherapy in a gemcitabine-resistant PDAC mouse model [136]. In another study, TAMs were observed to rapidly metabolize gemcitabine in vitro, and pharmacological depletion of these cells using clodronate liposomes enhanced therapeutic response to gemcitabine in tumor-bearing mice [137]. TAMs can also directly support chemoresistance by secreting insulin-like growth factors (IGF)- 1 and -2 which activate insulin/IGF receptors on pancreatic cancer cells [138], as well as Resistin, which binds to CAP-1 and TLR-4 on tumor cells and promotes gemcitabine resistance via STAT3 signaling [139].

\section{Therapeutic Opportunities for Targeting TAMs in PDAC}

Given the multi-faceted role of TAMs in promoting PDAC and their correlation with a poor prognosis, macrophages represent an attractive target to curb tumor development and progression. Indeed, TAM-targeting therapies have shown great promise in mouse models (Table 1), and a number of these agents are currently under clinical evaluation (Table 2). Major strategies targeting TAMs in PDAC include macrophage depletion, inhibiting macrophage recruitment, and macrophage reprogramming (Figure 4).

\subsection{Macrophage Depletion}

Clodronate-mediated depletion of macrophages has been shown to improve T-cell infiltration [23], reduce metastasis [39,140], and enhance therapeutic response to chemotherapy [137] in pre-clinical mouse models of PDAC. However, this method is non-specific to TAMs and eliminates other $\mathrm{CD} 11 \mathrm{~b}^{+}$phagocytotic cells in surrounding organs [39]. Meanwhile, the chemotherapeutic agent trabectedin activates caspase-8-dependent apoptosis in monocytes and macrophages, and results in the reactivation of tumor-infiltrating lymphocytes that secrete cytotoxic molecules to promote tumor cell death [141,142]. Lurbinectedin (PM00183) is an anti-cancer drug that triggers caspase-dependent apoptosis in cells by inducing DNA damage, and specifically depletes TAMs in the tumor microenvironment [143]. The combined use of lurbinectedin and gemcitabine induced a synergistic effect on PDAC xenografts by depleting TAMs, which led to cytidine deaminase downregulation in tumors and increased gemcitabine-mediated DNA damage [143].

Another method to deplete TAMs is by targeting CSF1R, which is expressed on the surface of circulating monocytes and tissue macrophages, and controls their survival, proliferation, differentiation, and chemotaxis [144]. CSF1R ${ }^{+}$TAMs sustain PDAC growth through T-cell suppression, while targeted depletion of these cells using the selective CSF1R inhibitor AZD7507 enhances T-cell responses and upregulates the expression of immunogenic gene signatures [145]. In an orthotopic model of PDAC, macrophage depletion via CSF1R inhibition decreased the number of tumor-initiating cells, improved the efficacy of chemotherapy, inhibited metastasis, and unleashed T-cell cytotoxicity [20]. Meanwhile, remaining TAMs are reprogrammed by CSF1/CSF1R blockade to support antigen presentation and bolster T-cell activation, which further restrains tumor progression [146]. 
Depletion of TAMs by targeting CSF1 has also been reported to enhance the tumoricidal activity of radiation, in line with its association with promoting adaptive immunity [147]. Likewise, combining CSF1/CSF1R inhibitors with immunotherapies including anti-PD1 and anti-CTLA4 induces a synergistic effect and induces potent tumor regression in experimental models of PDAC [146]. Similarly, a triple combination of anti-PD1, an anti-CSF1R antibody, and a PDAC vaccine (GVAX) converted exhausted $\mathrm{PD} 1^{+} \mathrm{T}$-cells to $\mathrm{CD} 137^{+}$activated effector T-cells, suggesting that adding a myeloid-targeting agent to vaccine-based cancer immunotherapy can reverse the anergy of T-cells in immune-quiescent tumors [148].

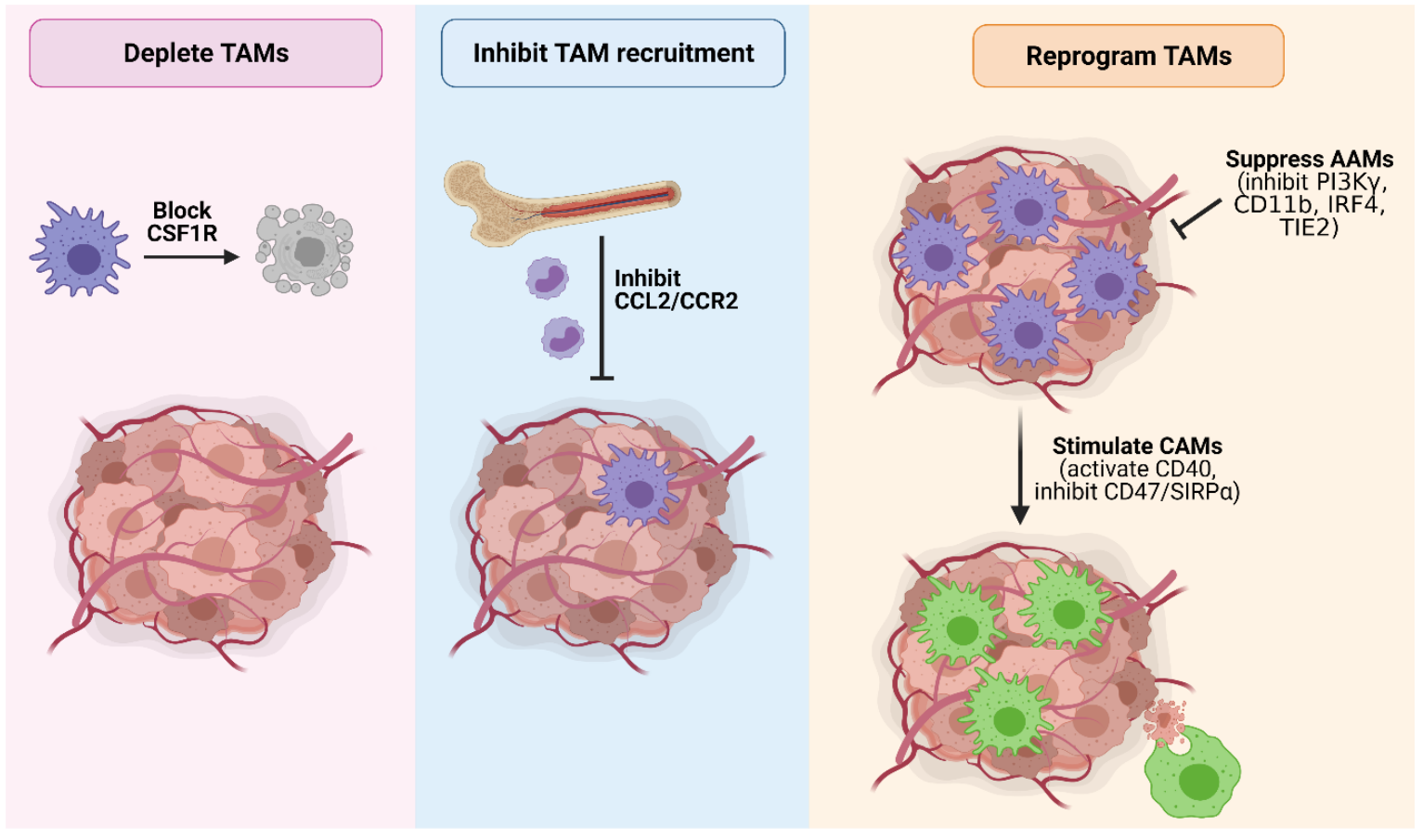

Figure 4. Strategies to therapeutically target TAMs in PDAC. Major TAM-targeting strategies in PDAC include (1) TAM depletion by blocking CSF1R signaling; (2) inhibition of TAM recruitment by blocking CCL2/CCR2 signaling; (3) suppressing the pro-tumorigenic activity of AAMs by inhibiting PI3K $\gamma$, CD11b, IRF4 or TIE2; and (4) reprogramming TAMs towards a tumoricidal classically-activated endotype via CD40 agonists or inhibition of the 'do not eat me' CD47/SIRP $\alpha$ signaling axis to promote tumor cell phagocytosis. Figure created in Biorender.

\subsection{Blocking Macrophage Recruitment}

Another strategy for targeting TAMs is by inhibiting their recruitment into the primary tumor. The CCL2/CCR2 signaling axis plays a central role in regulating the infiltration of circulating monocytes into the tumor microenvironment, making it a promising TAMtargeting therapy. In mice, CCR2 blockade prevents macrophage recruitment into the primary pancreatic tumor and pre-metastatic liver, and results in enhanced anti-tumor immunity, decreased tumor growth, and reduced metastasis [18,20,21]. A novel mechanism of radiotherapy resistance was recently discovered wherein PDAC cells respond to radiotherapy-induced stress by releasing high levels of CCL2 that recruit inflammatory monocytes to promote tumor proliferation and vascularity [19]. Accordingly, inhibition of inflammatory monocyte recruitment by antagonizing the CCL2/CCR2 chemokine axis in combination with ablative radiotherapy improved treatment response and enhanced survival [19].

A handful of inhibitors that selectively target CCL2/CCR2 signaling have completed Phase I clinical trials in pancreatic cancer (Table 2). An objective tumor response was seen in $49 \%$ of patients receiving FOLFIRINOX plus the CCR2 antagonist PF-04136309, with local tumor control achieved in 97\% of patients (NCT01413022) [149]. In another trial, the CCR2 specific antagonist CCX872 was used in combination with FOLFIRINOX to treat 
subjects with locally advanced or metastatic non-resectable pancreatic cancer. Circulating monocytes, inflammatory monocytes, and myeloid-derived suppressor cells were reduced by CCX872-B plus FOLFIRINOX therapy, and resulted in an improved overall survival compared to chemotherapy alone (NCT02345408) [150].

\subsection{Macrophage Reprogramming}

Strategies aimed at reprogramming TAMs include inhibiting immunosuppressive AAMs, or by re-educating macrophages towards a tumoricidal CAM endotype. Here, we discuss known targets of TAM repolarization that have been investigated in PDAC models, and provide an overall summary of these targets in (Table 1).

\subsubsection{PI3K $\gamma$}

PI3K $\gamma$ is a lipid kinase that promotes myeloid cell trafficking during inflammation and cancer [151], and drives the immunosuppressive transcriptional profile of TAMs [86]. In orthotopic and genetically-engineered mouse models of PDAC, inhibition of PI3K $\gamma$ slowed tumor growth, enhanced survival, and improved responsiveness to chemotherapy by inhibiting alternative macrophage polarization [86]. PI3K $\gamma$ depletion in TAMs significantly reduced the expression of immunosuppressive and pro-angiogenic genes, including Arg1, Tgfb, Il1b, Il6, and Vegfa. In contrast, the expression of immunostimulatory factors, including Ill2 and Ifng, was significantly enhanced in tumors and TAMs of PI3K $\gamma$-deficient mice and PI3K $\gamma$ inhibitor-treated animals [86]. These findings were corroborated in another study, where PI3K $\gamma$-mediated activation of the BTK signaling pathway in myeloid cells promoted the pro-tumorigenic activity of TAMs, while targeted inhibition of PI3K $\gamma$ or BTK in mice reprogrammed TAMs toward an inflammatory endotype that fostered CD8 T-cell cytotoxicity, suppressed PDAC growth, and improved responsiveness to chemotherapy $[152,153]$.

\subsubsection{RIP1}

Receptor-interacting protein 1 (RIP1) is an intracellular adaptor protein that relays signals from death receptors and TLRs to regulate inflammation, apoptosis, and necroptosis [154]. Pharmacologic inhibition of RIP1 reprograms TAMs towards a MHCII ${ }^{\mathrm{TiNF}} \alpha^{+} \mathrm{IFN} \gamma^{+}$ immunogenic phenotype in a STAT1-dependent manner, enhances cytotoxic T-cell activation, and impairs tumor growth in mice [155]. Notably, combined targeting of RIP1 and PD1 offers synergistic protection against primary PDAC and liver metastases, suggesting that RIP1 can be regarded as an immune 'check-point kinase'.

\subsubsection{CD40}

CD40 is a member of the TNFR superfamily that is constitutively expressed on all antigen-presenting cells (including TAMs and dendritic cells) and is critical for their activation and proliferation [156,157]. Binding of CD40 to its ligand CD40L, which is primarily expressed on the surface of activated T-cells, results in the upregulation of co-stimulatory molecules and proinflammatory cytokines that are crucial for T-cell priming $[156,157]$. In a spontaneous model of PDAC, administration of an agonistic anti-CD40 antibody led to the upregulation of MHC-II and CD86 on the surface of TAMs, and the production of pro-inflammatory cytokines including IL12, TNF $\alpha$, and IFN $\gamma$. These CD40activated macrophages rapidly infiltrated PDAC tumors and facilitated the depletion of the stroma [158]. In another study, a single dose of agonistic CD40 antibody in combination with gemcitabine and nab-paclitaxel enhanced TAM activation and the clonal expansion of T-cells that facilitated tumor destruction and durable remission [159]. The reprogramming of TAMs with anti-CD40 has also shown efficacy in increasing the intratumoral accumulation and longevity of TCR-engineered T-cells that promote tumor cell apoptosis [160]. Combining a T-cell-inducing vaccine with a PD1 antagonist and CD40 agonist antibody (triple therapy) induced T-cell priming and activation in mice with metastatic pancreatic cancer. The survival benefit was accompanied by a significant infiltration of IFN $\gamma$-, 
Granzyme B-, and TNF $\alpha$-secreting effector T-cells, demonstrating that the combined use of CD40 agonist and PD1 antagonist antibodies can reprogram immune resistant tumors in favor of anti-tumor immunity [161].

Monoclonal CD40 agonistic antibodies (e.g., CP-870,893, APX005M, RO7009789 and SEA-CD40) have been evaluated in clinical trials. In a cohort of 21 patients with surgically incurable PDAC, administration of CP-870,893 in combination with gemcitabine resulted in a partial response in 4 out of 21 patients, and stable disease in 11 out of 21 of patients (NCT00711191) [158]. Strikingly, one patient with a partial response showed significant reduction of their primary tumor and complete resolution of two hepatic metastatic lesions. A second patient with a partial response underwent surgical resection of the primary tumor after achieving a complete resolution of all hepatic metastases and a $64 \%$ reduction in the primary tumor [158]. The tolerability and efficacy of the agonistic anti-CD40 antibody APX005M was also evaluated in combination with chemotherapy (gemcitabine and nabpaclitaxel), with or without Nivolumab in a Phase $1 \mathrm{~b}$ study and showed clinical activity in patients with metastatic PDAC (NCT03214250) [162].

\subsection{4. $\mathrm{CD} 11 \mathrm{~b}$}

$\mathrm{CD} 11 \mathrm{~b}$ is an integrin molecule that is highly expressed on the surface of myeloid cells, and plays a key role in regulating their adhesion, chemotaxis, migration, phagocytosis, and survival $[163,164]$. Partial activation of CD11b using the small molecule agonist ADH-503 impaired tumor growth and improved survival in orthotopic and geneticallyengineered mouse models of PDAC $[165,166]$. Mechanistically, ADH-503 decreased the number of immunosuppressive myeloid cells in the tumor and reprogrammed remaining TAMs towards a tumoricidal endotype with improved antigen-presenting properties [166]. Gene expression profiling of TAMs isolated from tumors of ADH-503-treated mice also revealed downregulated expression of immunosuppressive genes (e.g., Il6, Tgf $\beta$, Arg1, Il10) and increased expression levels of the T-cell chemokine Cxcl10, which coincided with an increase in T-cell infiltration, activation, and proliferation [166]. Notably, CD11b agonism also synergized with anti-PD1 immune check-point blockade and promoted tumor regression, long-term survival, and lasting immunologic memory [166].

\subsubsection{CD47 and SIRP $\alpha$}

CD47 is a transmembrane protein expressed on normal cells, and acts as an antiphagocytic 'do not eat me' signal. The binding of CD47 to signal regulatory protein $\alpha$ $(\operatorname{SIRP} \alpha)$, which is mainly expressed by TAMs and dendritic cells, initiates a signaling cascade that prevents their phagocytic ability $[167,168]$. However, this mechanism is frequently hijacked by tumor cells that upregulate CD47, thereby enabling them to proliferate and avoid clearance by the immune system [169]. Furthermore, CD47-mediated protection against phagocytosis by macrophages prolongs the retention of exosomes in circulation, and enables cancer cells to manipulate their surroundings and support tumor growth [170]. Consequently, preventing CD47-SIRP $\alpha$ interactions removes this inhibitory check-point signal and enables the effective removal of cancer cells. Indeed, CD47 blockade using monoclonal antibodies facilitates the clearance of PDAC cells via macrophage-dependent phagocytosis in in vitro engulfment assays, and decreases metastatic tumor burden and improves survival in mice [140].

Single-cell RNA sequencing studies revealed that CD47 targeting induces compartmental remodeling of tumor-infiltrating immune cells within the PDAC tumor microenvironment by increasing the abundance of tumoricidal pro-inflammatory TAMs and reducing anti-inflammatory macrophages [171]. CD47 blockade also increased the number of intratumoral CD8 T-cells, and remodeled the T-cell cluster toward a more activated one [171]. Several microRNAs including miR340 and miR128 inversely correlate with CD47 expression in PDAC cancer cells and negatively regulate its expression [172,173]. Restoration of miR-340 expression in pancreatic cancer cells was sufficient to downregulate CD47 and promote the phagocytic ability of macrophages, while overexpression of miR-340 
reprogrammed TAMs towards a classically-activated endotype and enhanced anti-tumor immunity by increasing CD8 T-cell recruitment [173]. Thus, targeting CD47-SIRP $\alpha$ interactions promotes the functional reprogramming of macrophages towards an activated tumoricidal endotype and augments macrophage-mediated clearance of cancer cells.

\subsubsection{IRF4}

IRF4 is a key transcription factor that regulates alternative-macrophage polarization [174], and suppresses the differentiation of CAMs [175]. Accordingly, IRF4 deficiency results in decreased expression of prototypical AAM-associated genes including Arg1, Ym1, and Fizz1 [176]. In a syngeneic model of PDAC, inhibition of IRF4 via the immunomodulatory agent pomalidomide induced a shift from AAMs towards a pro-inflammatory population that decreased tumor fibrosis and promoted an immune-responsive environment with increased infiltration of activated T-cells [177]. Given that pomalidomide is FDA-approved and has also been shown to render pancreatic cancer cells susceptible to chemotherapy [178], these results highlight its potential as a combination therapy for the treatment of PDAC.

\subsubsection{TIE2}

TIE2 is a receptor tyrosine kinase that identifies a lineage of proangiogenic monocytes required for tumor vessel formation, and is commonly used as a marker of alternativelyactivated TAMs [179]. Of note, PDAC patients with a higher frequency of TIE2 ${ }^{+}$TAMs exhibit enhanced tumor neovascularization and a greater risk of developing metastatic disease $[110,180]$. The therapeutic benefit of targeting TIE2 ${ }^{+}$TAMs was demonstrated using the selective TIE2 inhibitor Rebastinib, which reduced pancreatic neuroendocrine tumor growth and metastasis in mice. Mechanistically, Rebastinib inhibited TIE2 ${ }^{+}$TAM infiltration and decreased the density of AAMs at the tumor invasive front, leading to impaired angiogenesis and tumor cell intravasation [180].

\section{Challenges Associated with Targeting TAMs}

Therapeutic modalities aimed at eliminating TAMs, inhibiting their infiltration, and/or reprogramming them towards a tumoricidal endotype have shown great potential in preclinical models. However, the effectiveness of these targeting strategies in preclinical models has not always translated into clinical trials [181]. This is in part due to the complexity associated with the nature and origin of TAMs (classically- versus alternativelyactivated; locally-proliferating tissue-resident versus systemically-recruited macrophages) that co-exist within the tumor microenvironment at various stages of cancer progression. Furthermore, in vivo delivery barriers (e.g., low drug solubility, short half-life, and poor cellular uptake), as well as the immunosuppressive and desmoplastic PDAC tumor microenvironment dampen the efficacy of TAM-targeting agents. Given the role of macrophages in pathogen clearance and tissue homeostasis, the timing and duration of macrophage-targeting therapies also warrants further investigation to minimize the risk of side effects.

\subsection{Differences between Mouse and Human Macrophages}

Mouse models have been instrumental in elucidating the contribution of immune cells in tumor development and progression. However, there are fundamental differences in the development, activation, and function of mouse and human immune cells [182]. For example, the cell surface marker F4/80 is commonly used to identify mouse macrophages but is undetectable on human cells [183]. While CD68 is used as an alternative to distinguish human macrophages, it can also be expressed by some stromal and cancer epithelial cells [184]. Mouse and human monocyte-derived macrophages also exhibit differences in their response to IL4 and IL13 in vitro. Stimulation of mouse macrophages with IL4/IL13 promotes the upregulation of the prototypical-AAM genes Ym1 and Arg1; however, this response is not observed in human macrophages [185]. Likewise, metabolism of the amino 
acid arginine by NOS2 and ARG1 is used to distinguish between CAMs and AAMs in mice, respectively, but this does not apply to human cells [29]. Thus, interspecies differences should be carefully considered to best translate our findings from pre-clinical models to human patients.

\subsection{Maximizing Translatability between Pre-Clinical Models and Human Patients}

In many pre-clinical studies, TAM-targeted therapies commence when the primary tumor reaches a designated size (e.g., $\sim 100 \mathrm{~mm}^{3}$ for subcutaneous tumor models). Treatment response is assessed by tumor shrinkage, impaired tumor growth, and/or Kaplan-Meier survival analysis. Although this method is a useful way of measuring the therapeutic efficacy of anti-cancer drugs in primary tumors, it does not reflect how most therapies are evaluated in clinical trials in which patients are enrolled with metastatic disease and with prior lines of failed treatment. Furthermore, many studies have shown that the tumor microenvironment at the primary site can dramatically differ from that of metastatic lesions $[186,187]$. While CSF1R inhibitors and CD40 agonists potently reduce tumor growth in mice, the combined use of Emactuzumab (anti-CSF1R monoclonal antibody) with Selicrelumab (agonistic CD40 monoclonal antibody) in patients with metastatic PDAC has not translated into objective clinical responses (NCT02760797) [188]. Likewise, CSF1R blockade and anti-PD1 therapy induces tumor regression in mice [146], but shows limited anti-tumor activity in PDAC patients with advanced disease (NCT02713529) [189]. To maximize the translational impact of pre-clinical studies, a complementary approach may include the use of models that mimic the stage of cancer in which the therapy is to be tested in clinical trials. One example to recapitulate advanced disease in mice is the intrasplenic pancreatic tumor model, in which syngeneic PDAC tumor cells are injected into the spleen and migrate into the liver via the portal vein, which is a common route of metastasis in human PDAC patients [190]. Likewise, the pre-clinical evaluation of TAM-targeting therapies in a neo-adjuvant setting or in combination with existing treatment paradigms to better emulate the design of clinical trials may also improve the chances of translational success.

\subsection{Limited Markers to Discriminate between TAMs and Normal Macrophages}

To maximize the translatability of pre-clinical studies, a thorough understanding of how TAMs evolve during malignancy, following therapy, and between primary and metastatic tumors is required for both mouse and human PDAC. Central to this is the identification of novel TAM targets that will allow the selective targeting of immunosuppressive or tumor-promoting endotypes, as there are currently limited markers to distinguish them from normal macrophages in non-tumor tissues. To this end, increased accessibility to novel technologies such as single-cell sequencing, spatial transcriptomics, and high-resolution imaging is anticipated to achieve a more comprehensive understanding of TAM subsets and their functional heterogeneity within the tumor microenvironment, as well as the identification of novel TAM targets to improve patient outcomes in PDAC [191].

\subsection{Dissecting the Heterogeneity of Human PDAC Tumors}

Compared to mouse PDAC tumors that are relatively homogenous, human PDAC tumors exhibit a high degree of heterogeneity between individuals (intertumoral heterogeneity), and within the same tumor (intratumor heterogeneity). Stratification models based on transcriptomic and genomic signatures have identified the existence of geneticallydistinct PDAC subtypes with prognostic and biological relevance [192-199]. Both squamous/mesenchymal and immunogenic subtypes exhibit an enrichment of macrophage gene signatures compared to the pancreatic progenitor or aberrant differentiated endocrine exocrine (ADEX) subtypes, suggesting the differential contribution of macrophages in these tumors [194]. These findings were corroborated in another study demonstrating that CSF1R $^{+}$TAMs maintain key transcriptional signatures that define the squamous subtype of human PDAC [145]. Although one might speculate that TAM-targeting strategies may be more beneficial in subtypes with higher macrophage density, recent works using single-cell 
transcriptomics demonstrate that several subtypes may co-exist within a tumor $[199,200]$. Thus, targeting the immune cell compartment of PDAC without understanding its complexity could have deleterious or negligible impacts on clinical outcomes.

\subsection{Minimizing off-Target Side Effects}

While pharmacologic depletion of TAMs has shown remarkable success in controlling PDAC in experimental models, its translational value in human patients remains limited. A major barrier to clinical translation is the availability of efficient and safe methods to deliver TAM-depleting agents into tumors following systemic administration. This is particularly important because systemic macrophage depletion in an immunocompromised patient undergoing chemotherapy may increase their vulnerability to infections, or result in impaired pathogen clearance. Tissue-resident macrophages are also important in maintaining homeostasis, and the prolonged depletion of these cells may impair organ function [201,202]. For example, transient ablation of alveolar macrophages impairs innate immune responses, and leads to severe influenza infection in mice [203]. Meanwhile, systemic macrophage depletion may disrupt immune balance by causing a compensatory influx of neutrophils that promote excessive inflammation [204]. Indeed, CSF1R inhibition has been reported to trigger an increase of granulocyte-specific chemokines produced by cancer-associated fibroblasts, resulting in an influx of granulocytes into tumors [205]. These adverse effects pose a challenge for the administration of CSF1R inhibitors, but may be overcome by combining anti-CSF1R drugs with other therapeutic methods. For example, combining inhibition of CXCR2 with CSF1R stopped the recruitment of neutrophil/granulocytes and improved the therapeutic efficacy of anti-PD1 immune check-point blockade [205]. Meanwhile, dual blockade of PI3k $\gamma$ and CSF1R using a nano-micelle encapsulating the PI3K $\gamma$ inhibitor BEZ235 and CSF1R-siRNA reduced AAMs, increased the abundance of CAMs, and suppressed tumor infiltration of myeloid-derived suppressor cells in mice [206].

Although macrophage reprogramming represents a more sophisticated method than systemic depletion, one significant challenge is maintaining the delicate balance between the tumoricidal and immune-regulating functions of TAMs. The prolonged stimulation of CAMs could result in chronic inflammation and tissue damage, while loss of AAMs may result in impaired wound-healing. Therefore, targeted strategies that can selectively reprogram TAMs within the tumor microenvironment without affecting other macrophages in normal organs warrants further investigation. Indeed, recent advances in nanotechnology and biomedical engineering have given rise to novel drug formulations based on nanoparticles to overcome issues surrounding non-specificity and promote cell-specific uptake [207]. However, further research is required to comprehensively characterize cell surface markers and signaling pathways that can uniquely differentiate TAMs from normal macrophages in order to prevent undesired side effects.

\section{Concluding Remarks}

Given the multi-faceted role of TAMs in promoting PDAC and their correlation with a poor prognosis, macrophages represent an attractive therapeutic target to impair tumor development and progression. Strategies aimed at targeting TAMs in pre-clinical models include macrophage depletion, inhibiting their recruitment, or re-educating immunosuppressive TAMs towards a tumoricidal endotype. Many of these therapeutic agents also demonstrate complementary effects when combined with chemotherapy and immune check-point blockade, suggesting the additive benefit of targeting TAMs alongside other cell populations to enhance anti-tumor immunity. However, despite showing great potential in pre-clinical studies, the efficacy of these drugs has not always translated into clinical trials. This is in part due to the complexity associated with the nature and origin of TAMs, and the diverse heterogeneity of PDAC tumors in humans compared to mice. Further research is therefore required to comprehensively characterize TAM subsets within the tumor microenvironment, and identify novel TAM targets that will enable the selective targeting of tumor-promoting endotypes to improve patient outcomes in PDAC. 
Table 1. Summary of selected targets of TAM inhibition in PDAC mouse models.

\begin{tabular}{|c|c|c|c|}
\hline Pathway & Method & Effect & Refs. \\
\hline \multirow{7}{*}{ Macrophage depletion } & Administration of macrophage toxin $\mathrm{GdCl}_{3}$ & $\begin{array}{l}\text { Blocked acinar-to-ductal metaplasia and the formation of pancreatic intraepithelial } \\
\text { neoplastic lesions. }\end{array}$ & {$[37,38]$} \\
\hline & Administration of Trabectedin & $\begin{array}{l}\text { Activated caspase-8-dependent apoptosis in TAMs, and resulted in the reactivation of } \\
\text { tumor-infiltrating lymphocytes that promote tumor cell death. }\end{array}$ & {$[141,142]$} \\
\hline & Administration of clodronate-liposomes & $\begin{array}{l}\text { Reduced tumor formation and metastasis by enhancing T-cell infiltration. Also } \\
\text { synergized with gemcitabine chemotherapy to elicit a potent anti-tumor response. }\end{array}$ & {$[23,39,137,140]$} \\
\hline & Administration of Lurbinectedin (PM00183) & Activated caspase-dependent apoptosis in cells by inducing DNA damage. & [143] \\
\hline & \multirow{3}{*}{ Inhibiting CSF1R } & $\begin{array}{l}\text { Decreased tumor-initiating cells, reduced immunosuppression, and improved } \\
\text { chemotherapeutic responses. }\end{array}$ & [20] \\
\hline & & $\begin{array}{l}\text { Reduced tumor burden due to increased tumor cell death and an enhanced T-cell } \\
\text { immune response. }\end{array}$ & [145] \\
\hline & & Improved response to immune check-point blockade, resulting in tumor regression. & [146] \\
\hline \multirow{3}{*}{ Macrophage recruitment } & \multirow{3}{*}{ Inhibiting CCR2 } & Enhanced anti-tumor immunity, decreased tumor growth, and reduced metastasis. & [21] \\
\hline & & $\begin{array}{l}\text { Decreased number of cancer stem cells in pancreatic tumors and improved response to } \\
\text { chemotherapy. }\end{array}$ & [20] \\
\hline & & $\begin{array}{l}\begin{array}{l}\text { Suppressed radiation-induced neovascularization and enhanced the efficacy of } \\
\text { radiotherapy. }\end{array}\end{array}$ & [19] \\
\hline \multirow{7}{*}{$\begin{array}{l}\text { Macrophage reprogramming } \\
\text { (suppressing AAM polarization) }\end{array}$} & \multirow{2}{*}{ Inhibiting $\mathrm{PI} 3 \mathrm{~K} \gamma$} & Inhibited tumor cell invasion, metastasis, and desmoplasia. & {$[86,151]$} \\
\hline & & $\begin{array}{l}\text { Slowed tumor development, impeded late-stage tumor growth and improved } \\
\text { responsiveness to chemotherapy. }\end{array}$ & {$[152,153]$} \\
\hline & Inhibiting CD11b & $\begin{array}{l}\text { Reduced expression levels of immunosuppressive genes in TAMs, and enhanced T-cell } \\
\text { immunity. }\end{array}$ & [166] \\
\hline & Inhibiting IRF4 & $\begin{array}{l}\text { Depleted pancreatic lesions of AAMs and generated an inflammatory and } \\
\text { immune-responsive environment. }\end{array}$ & [177] \\
\hline & Inhibiting Mstr1 & $\begin{array}{l}\text { Decreased tumor size, suppressed alternative macrophage polarization, and enhanced } \\
\text { T cell infiltration. }\end{array}$ & [208] \\
\hline & Administration of IL27 & $\begin{array}{l}\text { Inhibited M2 macrophages polarization, dampened the proliferation, migration, and } \\
\text { metastasis of pancreatic cancer cells, and enhanced the efficacy of gemcitabine. }\end{array}$ & [209] \\
\hline & Inhibition of TIE2 & $\begin{array}{l}\text { Reduced tumor angiogenesis and presence of alternatively-activated macrophages at } \\
\text { the invasive tumor front. }\end{array}$ & [180] \\
\hline
\end{tabular}


Table 1. Cont.

\begin{tabular}{|c|c|c|c|c|c|c|c|}
\hline \multicolumn{2}{|c|}{ Pathway } & \multicolumn{2}{|c|}{ Method } & \multicolumn{3}{|c|}{ Effect } & Refs. \\
\hline \multirow{5}{*}{\multicolumn{2}{|c|}{$\begin{array}{l}\text { Macrophage reprogramming } \\
\text { (stimulating CAM polarization) }\end{array}$}} & \multicolumn{2}{|c|}{ Inhibiting RIP1 } & \multicolumn{3}{|c|}{$\begin{array}{l}\text { Reprogrammed TAMs towards an } \mathrm{MHCI}{ }^{\text {hi }} \mathrm{TNF} \alpha^{+} \mathrm{IFN} \gamma^{+} \text {immunogenic phenotype, } \\
\text { and enhanced cytotoxic T-cell activation. }\end{array}$} & [155] \\
\hline & & \multirow{3}{*}{\multicolumn{2}{|c|}{ Activating CD40 }} & \multicolumn{3}{|c|}{$\begin{array}{l}\text { Improved infiltration of activated macrophages into tumors and depletion of tumor } \\
\text { stroma. When combined with chemotherapy, anti-CD40 enhanced TAM activation and } \\
\text { the clonal expansion of T-cells that resulted in tumor remission. }\end{array}$} & {$[158,159]$} \\
\hline & & & & \multicolumn{3}{|c|}{$\begin{array}{l}\text { Increased intratumoral accumulation and longevity of TCR-engineered T-cells that } \\
\text { promote tumor cell apoptosis. }\end{array}$} & [160] \\
\hline & & & & \multicolumn{3}{|c|}{$\begin{array}{l}\text { When combined with a T-cell-inducing vaccine and anti-PD1 immune check-point } \\
\text { blockade, anti-CD40 reprogrammed macrophages improved T-cell priming and } \\
\text { activation. }\end{array}$} & [161] \\
\hline & & \multicolumn{2}{|c|}{ Blocking CD47 } & \multicolumn{3}{|c|}{$\begin{array}{l}\text { Improved macrophage-dependent phagocytosis of cancer cells, reprogrammed TAMs } \\
\text { towards a pro-inflammatory tumoricidal endotype, and increased the number of } \\
\text { intratumoral CD8 T-cells. }\end{array}$} & {$[140,171]$} \\
\hline \multirow{9}{*}{ Small molecule } & \multirow{2}{*}{ CSF1R } & Pexidartinib & Durv & DL1) & AstraZeneca and Plexxikon & NCT02777710 & Complete [210] \\
\hline & & ARRY-382 & Pembr & -PD1) & Pfizer & NCT02880371 & Complete [211] \\
\hline & \multirow{2}{*}{ CCR2 } & PF-04136309 & & I & Washington University & NCT01413022 & Complete [149] \\
\hline & & CCX872 & & I & ChemoCentryx & NCT02345408 & Ongoing [150] \\
\hline & VEGFR & Cediranib & Olapa & bitor) & AstraZeneca & NCT02498613 & $\begin{array}{l}\text { Ongoing, } \\
\text { unpublished }\end{array}$ \\
\hline & TGF $\beta$ & Galunisertib & Durv & DL1) & AstraZeneca & NCT02734160 & Complete [212] \\
\hline & \multirow[t]{2}{*}{ PI3K } & Buparlisib (BKM120) & & I & UNC Lineberger & NCT01571024 & $\begin{array}{l}\text { Complete, } \\
\text { unpublished }\end{array}$ \\
\hline & & LY3023414 & Gemcital & ine and & Eli Lilly and Company & NCT02981342 & Complete [213] \\
\hline & BTK & Ibrutinib & Nab-pacl & citabine & Pharmacyclics LLC & NCT02436668 & Complete [214] \\
\hline
\end{tabular}


Table 2. Cont.

\begin{tabular}{|c|c|c|c|c|c|c|c|}
\hline Class & Target & Compound/Class & Combination Partners & Phase & Sponsor & Trials ID & Status \\
\hline \multirow{10}{*}{$\begin{array}{l}\text { Monoclonal } \\
\text { antibody }\end{array}$} & \multirow{7}{*}{ CSF1R } & $\begin{array}{l}\text { Emactuzumab } \\
\text { (RG7155) }\end{array}$ & RG7876 (anti-CD40) & I & Hoffmann-La Roche & NCT02760797 & Complete [188] \\
\hline & & AMG820 & Pembrolizumab (anti-PD1) & I & Amgen & NCT02713529 & Complete [189] \\
\hline & & $\begin{array}{l}\text { Cabiralizumab } \\
\text { (FPA008) }\end{array}$ & Nivolumab (anti-PD1) & I & FivePrime/BMS & NCT02526017 & Complete [215] \\
\hline & & MCS110 & PDR001 (anti-PD1) & $\mathrm{I} / \mathrm{II}$ & Novartis & NCT02807844 & Complete [216] \\
\hline & & Cabiralizumab & $\begin{array}{l}\text { Nivolumab (anti-PD1) and } \\
\text { Stereotactic Body Radiotherapy }\end{array}$ & II & NYU Langone Health & NCT03599362 & Complete [217] \\
\hline & & Cabiralizumab & $\begin{array}{c}\text { Nivolumab (anti-PD1), } \\
\text { gemcitabine, Nab-paclitaxel }\end{array}$ & II & Bristol-Myers Squibb & NCT03336216 & Ongoing[215] \\
\hline & & $\begin{array}{c}\text { IMC-CS4 } \\
\text { (LY3022855) }\end{array}$ & $\begin{array}{c}\text { Cyclophosphamide, } \\
\text { pembrolizumab (anti-PD1), GVAX }\end{array}$ & I & $\begin{array}{c}\text { Merck Sharp \& Dohme Corp.Eli } \\
\text { Lilly and Company }\end{array}$ & NCT03153410 & $\begin{array}{l}\text { Ongoing, } \\
\text { unpublished }\end{array}$ \\
\hline & \multirow{3}{*}{ CD40 } & CP-870,893 & Gemcitabine & I & Hoffmann-La Roche & NCT00711191 & Complete [158] \\
\hline & & RO7009789 & Nab-paclitaxel and Gemcitabine & I & $\begin{array}{l}\text { Abramson Cancer Center of the } \\
\text { University of Pennsylvania }\end{array}$ & NCT02588443 & $\begin{array}{l}\text { Complete, } \\
\text { unpublished }\end{array}$ \\
\hline & & SEA-CD40 & $\begin{array}{c}\text { Pembrolizumab, Gemcitabine, } \\
\text { and Nab-Paclitaxel }\end{array}$ & I & Seagen Inc. & NCT02376699 & Ongoing[218] \\
\hline
\end{tabular}


Author Contributions: A.R.P. and M.E. wrote the manuscript and designed the figures. All authors have read and agreed to the published version of the manuscript.

Funding: This work was supported in parts through the Victorian State Government Operational Infrastructure Support, the National Health and Medical Research Council (NHMRC) of Australia project grants 1025239, 1079257, 1081373, and 1092788. M.E. received funding from Ludwig Cancer Research and is a NHMRC Investigator. A.R.P. is supported by a Jack Brockhoff Early Career Medical Research Grant (JBF4656-2019), a Tour de Cure Early-Career Research Grant, and an NHMRC Peter Doherty Early Career Fellowship (GNT1166447).

Institutional Review Board Statement: Not applicable.

Informed Consent Statement: Not applicable.

Data Availability Statement: Not applicable.

Conflicts of Interest: The authors declare no potential conflict of interest.

\section{References}

1. Siegel, R.L.; Miller, K.D.; Jemal, A. Cancer statistics, 2020. CA Cancer J. Clin. 2020, 70, 7-30. [CrossRef]

2. Rawla, P.; Sunkara, T.; Gaduputi, V. Epidemiology of Pancreatic Cancer: Global Trends, Etiology and Risk Factors. World J. Oncol. 2019, 10, 10-27. [CrossRef] [PubMed]

3. Maitra, A.; Hruban, R.H. Pancreatic cancer. Annu. Rev. Pathol. 2008, 3, 157-188. [CrossRef] [PubMed]

4. Adamska, A.; Domenichini, A.; Falasca, M. Pancreatic Ductal Adenocarcinoma: Current and Evolving Therapies. Int. J. Mol. Sci. 2017, 18, 1338. [CrossRef] [PubMed]

5. Conroy, T.; Desseigne, F.; Ychou, M.; Bouche, O.; Guimbaud, R.; Becouarn, Y.; Adenis, A.; Raoul, J.L.; Gourgou-Bourgade, S.; de la Fouchardiere, C.; et al. FOLFIRINOX versus gemcitabine for metastatic pancreatic cancer. N. Engl. J. Med. 2011, 364, 1817-1825. [CrossRef] [PubMed]

6. Von Hoff, D.D.; Ervin, T.; Arena, F.P.; Chiorean, E.G.; Infante, J.; Moore, M.; Seay, T.; Tjulandin, S.A.; Ma, W.W.; Saleh, M.N.; et al. Increased survival in pancreatic cancer with nab-paclitaxel plus gemcitabine. N. Engl. J. Med. 2013, 369, 1691-1703. [CrossRef]

7. Hidalgo, M.; Cascinu, S.; Kleeff, J.; Labianca, R.; Lohr, J.M.; Neoptolemos, J.; Real, F.X.; Van Laethem, J.L.; Heinemann, V. Addressing the challenges of pancreatic cancer: Future directions for improving outcomes. Pancreatology 2015, 15, 8-18. [CrossRef]

8. Barugola, G.; Partelli, S.; Marcucci, S.; Sartori, N.; Capelli, P.; Bassi, C.; Pederzoli, P.; Falconi, M. Resectable pancreatic cancer: Who really benefits from resection? Ann. Surg. Oncol. 2009, 16, 3316-3322. [CrossRef]

9. Hishinuma, S.; Ogata, Y.; Tomikawa, M.; Ozawa, I.; Hirabayashi, K.; Igarashi, S. Patterns of recurrence after curative resection of pancreatic cancer, based on autopsy findings. J. Gastrointest. Surg. 2006, 10, 511-518. [CrossRef]

10. Chu, G.C.; Kimmelman, A.C.; Hezel, A.F.; DePinho, R.A. Stromal biology of pancreatic cancer. J. Cell. Biochem. 2007, 101, 887-907. [CrossRef]

11. Erkan, M.; Hausmann, S.; Michalski, C.W.; Fingerle, A.A.; Dobritz, M.; Kleeff, J.; Friess, H. The role of stroma in pancreatic cancer: Diagnostic and therapeutic implications. Nat. Rev. Gastroenterol. Hepatol. 2012, 9, 454-467. [CrossRef]

12. Provenzano, P.P.; Hingorani, S.R. Hyaluronan, fluid pressure, and stromal resistance in pancreas cancer. Br. J. Cancer 2013, 108, 1-8. [CrossRef]

13. Wörmann, S.M.; Diakopoulos, K.N.; Lesina, M.; Algül, H. The immune network in pancreatic cancer development and progression. Oncogene 2014, 33, 2956-2967. [CrossRef]

14. Clark, C.E.; Hingorani, S.R.; Mick, R.; Combs, C.; Tuveson, D.A.; Vonderheide, R.H. Dynamics of the immune reaction to pancreatic cancer from inception to invasion. Cancer Res. 2007, 67, 9518-9527. [CrossRef]

15. Beatty, G.L.; Eghbali, S.; Kim, R. Deploying Immunotherapy in Pancreatic Cancer: Defining Mechanisms of Response and Resistance. Am. Soc. Clin. Oncol. Educ. Book 2017, 37, 267-278. [CrossRef]

16. Yu, M.; Guan, R.; Hong, W.; Zhou, Y.; Lin, Y.; Jin, H.; Hou, B.; Jian, Z. Prognostic value of tumor-associated macrophages in pancreatic cancer: A meta-analysis. Cancer Manag. Res. 2019, 11, 4041-4058. [CrossRef] [PubMed]

17. Zhu, Y.; Herndon, J.M.; Sojka, D.K.; Kim, K.W.; Knolhoff, B.L.; Zuo, C.; Cullinan, D.R.; Luo, J.; Bearden, A.R.; Lavine, K.J.; et al. Tissue-Resident Macrophages in Pancreatic Ductal Adenocarcinoma Originate from Embryonic Hematopoiesis and Promote Tumor Progression. Immunity 2017, 47, 323-338.e326. [CrossRef]

18. Nywening, T.M.; Belt, B.A.; Cullinan, D.R.; Panni, R.Z.; Han, B.J.; Sanford, D.E.; Jacobs, R.C.; Ye, J.; Patel, A.A.; Gillanders, W.E.; et al. Targeting both tumour-associated CXCR2 ${ }^{+}$neutrophils and CCR2 ${ }^{+}$macrophages disrupts myeloid recruitment and improves chemotherapeutic responses in pancreatic ductal adenocarcinoma. Gut 2018, 67, 1112-1123. [CrossRef] [PubMed]

19. Kalbasi, A.; Komar, C.; Tooker, G.M.; Liu, M.; Lee, J.W.; Gladney, W.L.; Ben-Josef, E.; Beatty, G.L. Tumor-Derived CCL2 Mediates Resistance to Radiotherapy in Pancreatic Ductal Adenocarcinoma. Clin. Cancer Res. Off. J. Am. Assoc. Cancer Res. 2017, 23, 137-148. [CrossRef] [PubMed] 
20. Mitchem, J.B.; Brennan, D.J.; Knolhoff, B.L.; Belt, B.A.; Zhu, Y.; Sanford, D.E.; Belaygorod, L.; Carpenter, D.; Collins, L.; PiwnicaWorms, D.; et al. Targeting tumor-infiltrating macrophages decreases tumor-initiating cells, relieves immunosuppression, and improves chemotherapeutic responses. Cancer Res. 2013, 73, 1128-1141. [CrossRef]

21. Sanford, D.E.; Belt, B.A.; Panni, R.Z.; Mayer, A.; Deshpande, A.D.; Carpenter, D.; Mitchem, J.B.; Plambeck-Suess, S.M.; Worley, L.A.; Goetz, B.D.; et al. Inflammatory monocyte mobilization decreases patient survival in pancreatic cancer: A role for targeting the CCL2/CCR2 axis. Clin. Cancer Res. 2013, 19, 3404-3415. [CrossRef]

22. Calderon, B.; Carrero, J.A.; Ferris, S.T.; Sojka, D.K.; Moore, L.; Epelman, S.; Murphy, K.M.; Yokoyama, W.M.; Randolph, G.J.; Unanue, E.R. The pancreas anatomy conditions the origin and properties of resident macrophages. J. Exp. Med. 2015, 212, 1497-1512. [CrossRef]

23. Beatty, G.L.; Winograd, R.; Evans, R.A.; Long, K.B.; Luque, S.L.; Lee, J.W.; Clendenin, C.; Gladney, W.L.; Knoblock, D.M.; Guirnalda, P.D.; et al. Exclusion of T Cells From Pancreatic Carcinomas in Mice Is Regulated by Ly6Clow F4/80 Extratumoral Macrophages. Gastroenterology 2015, 149, 201-210. [CrossRef]

24. Poh, A.R.; Ernst, M. Targeting Macrophages in Cancer: From Bench to Bedside. Front. Oncol. 2018, 8, 49. [CrossRef] [PubMed]

25. Murray, P.J.; Allen, J.E.; Biswas, S.K.; Fisher, E.A.; Gilroy, D.W.; Goerdt, S.; Gordon, S.; Hamilton, J.A.; Ivashkiv, L.B.; Lawrence, T.; et al. Macrophage activation and polarization: Nomenclature and experimental guidelines. Immunity 2014, 41, 14-20. [CrossRef]

26. Biswas, S.K.; Mantovani, A. Macrophage plasticity and interaction with lymphocyte subsets: Cancer as a paradigm. Nat. Immunol. 2010, 11, 889-896. [CrossRef] [PubMed]

27. Mosser, D.; Edwards, J. Exploring the full spectrum of macrophage activation. Nat. Rev. Immunol. 2008, 8, 958-969. [CrossRef]

28. Sica, A.; Larghi, P.; Mancino, A.; Rubino, L.; Porta, C.; Totaro, M.; Rimoldi, M.; Biswas, S.; Allavena, P.; Mantovani, A. Macrophage polarisation in tumour progression. Semin. Cancer Biol. 2008, 18, 349-355. [CrossRef]

29. Martinez, F.O.; Gordon, S.; Locati, M.; Mantovani, A. Transcriptional profiling of the human monocyte-to-macrophage differentiation and polarization: New molecules and patterns of gene expression. J. Immunol. 2006, 177, 7303-7311. [CrossRef] [PubMed]

30. Abdelaziz, M.H.; Abdelwahab, S.F.; Wan, J.; Cai, W.; Huixuan, W.; Jianjun, C.; Kumar, K.D.; Vasudevan, A.; Sadek, A.; Su, Z.; et al. Alternatively activated macrophages; a double-edged sword in allergic asthma. J. Transl. Med. 2020, 18, 58. [CrossRef]

31. Wang, L.-X.; Zhang, S.-X.; Wu, H.-J.; Rong, X.-L.; Guo, J. M2b macrophage polarization and its roles in diseases. J. Leukoc. Biol. 2019, 106, 345-358. [CrossRef]

32. Zizzo, G.; Hilliard, B.A.; Monestier, M.; Cohen, P.L. Efficient clearance of early apoptotic cells by human macrophages requires M2c polarization and MerTK induction. J. Immunol. 2012, 189, 3508-3520. [CrossRef] [PubMed]

33. Wang, Q.; Ni, H.; Lan, L.; Wei, X.; Xiang, R.; Wang, Y. Fra-1 protooncogene regulates IL-6 expression in macrophages and promotes the generation of M2d macrophages. Cell Res. 2010, 20, 701-712. [CrossRef]

34. Ferrante, C.J.; Pinhal-Enfield, G.; Elson, G.; Cronstein, B.N.; Hasko, G.; Outram, S.; Leibovich, S.J. The adenosine-dependent angiogenic switch of macrophages to an M2-like phenotype is independent of interleukin-4 receptor alpha (IL-4R $\alpha$ ) signaling Inflammation 2013, 36, 921-931. [CrossRef] [PubMed]

35. Lewis, C.E.; Pollard, J.W. Distinct role of macrophages in different tumor microenvironments. Cancer Res. 2006, 66, 605-612. [CrossRef] [PubMed]

36. Tekin, C.; Aberson, H.L.; Bijlsma, M.F.; Spek, C.A. Early macrophage infiltrates impair pancreatic cancer cell growth by TNF- $\alpha$ secretion. BMC Cancer 2020, 20, 1183. [CrossRef]

37. Liou, G.-Y.; Döppler, H.; Necela, B.; Krishna, M.; Crawford, H.C.; Raimondo, M.; Storz, P. Macrophage-secreted cytokines drive pancreatic acinar-to-ductal metaplasia through NF-кB and MMPs. J. Cell Biol. 2013, 202, 563-577. [CrossRef]

38. Liou, G.Y.; Döppler, H.; Necela, B.; Edenfield, B.; Zhang, L.; Dawson, D.W.; Storz, P. Mutant KRAS-induced expression of ICAM-1 in pancreatic acinar cells causes attraction of macrophages to expedite the formation of precancerous lesions. Cancer Discov. 2015, 5, 52-63. [CrossRef] [PubMed]

39. Griesmann, H.; Drexel, C.; Milosevic, N.; Sipos, B.; Rosendahl, J.; Gress, T.M.; Michl, P. Pharmacological macrophage inhibition decreases metastasis formation in a genetic model of pancreatic cancer. Gut 2017, 66, 1278-1285. [CrossRef]

40. Penny, H.L.; Sieow, J.L.; Adriani, G.; Yeap, W.H.; See Chi Ee, P.; San Luis, B.; Lee, B.; Lee, T.; Mak, S.Y.; Ho, Y.S.; et al. Warburg metabolism in tumor-conditioned macrophages promotes metastasis in human pancreatic ductal adenocarcinoma. Oncoimmunology 2016, 5, e1191731. [CrossRef]

41. Kimsey, T.F.; Campbell, A.S.; Albo, D.; Wilson, M.; Wang, T.N. Co-localization of macrophage inflammatory protein-3alpha (Mip-3alpha) and its receptor, CCR6, promotes pancreatic cancer cell invasion. Cancer J. 2004, 10, 374-380. [CrossRef] [PubMed]

42. Kleeff, J.; Kusama, T.; Rossi, D.L.; Ishiwata, T.; Maruyama, H.; Friess, H.; Büchler, M.W.; Zlotnik, A.; Korc, M. Detection and localization of Mip-3alpha/LARC/Exodus, a macrophage proinflammatory chemokine, and its CCR6 receptor in human pancreatic cancer. Int. J. Cancer 1999, 81, 650-657. [CrossRef]

43. Campbell, A.S.; Albo, D.; Kimsey, T.F.; White, S.L.; Wang, T.N. Macrophage inflammatory protein-3alpha promotes pancreatic cancer cell invasion. J. Surg. Res. 2005, 123, 96-101. [CrossRef] [PubMed]

44. Liu, B.; Jia, Y.; Ma, J.; Wu, S.; Jiang, H.; Cao, Y.; Sun, X.; Yin, X.; Yan, S.; Shang, M.; et al. Tumor-associated macrophage-derived CCL20 enhances the growth and metastasis of pancreatic cancer. Acta Biochim. Biophys. Sin. 2016, 48, 1067-1074. [CrossRef]

45. Farrow, B.; Evers, B.M. Inflammation and the development of pancreatic cancer. Surg. Oncol. 2002, 10, 153-169. [CrossRef] 
46. Stone, M.L.; Beatty, G.L. Cellular determinants and therapeutic implications of inflammation in pancreatic cancer. Pharmacol. Ther. 2019, 201, 202-213. [CrossRef] [PubMed]

47. Kirkegård, J.; Mortensen, F.V.; Cronin-Fenton, D. Chronic Pancreatitis and Pancreatic Cancer Risk: A Systematic Review and Meta-analysis. Am. J. Gastroenterol. 2017, 112, 1366-1372. [CrossRef] [PubMed]

48. Midha, S.; Chawla, S.; Garg, P.K. Modifiable and non-modifiable risk factors for pancreatic cancer: A review. Cancer Lett. 2016, 381, 269-277. [CrossRef] [PubMed]

49. Renehan, A.G.; Tyson, M.; Egger, M.; Heller, R.F.; Zwahlen, M. Body-mass index and incidence of cancer: A systematic review and meta-analysis of prospective observational studies. Lancet 2008, 371, 569-578. [CrossRef]

50. Korc, M.; Jeon, C.Y.; Edderkaoui, M.; Pandol, S.J.; Petrov, M.S. Tobacco and alcohol as risk factors for pancreatic cancer. Best Pract. Res. Clin. Gastroenterol. 2017, 31, 529-536. [CrossRef] [PubMed]

51. Anderson, M.A.; Zolotarevsky, E.; Cooper, K.L.; Sherman, S.; Shats, O.; Whitcomb, D.C.; Lynch, H.T.; Ghiorzo, P.; Rubinstein, W.S.; Vogel, K.J.; et al. Alcohol and tobacco lower the age of presentation in sporadic pancreatic cancer in a dose-dependent manner: A multicenter study. Am. J. Gastroenterol. 2012, 107, 1730-1739. [CrossRef]

52. Dugernier, T.L.; Laterre, P.F.; Wittebole, X.; Roeseler, J.; Latinne, D.; Reynaert, M.S.; Pugin, J. Compartmentalization of the inflammatory response during acute pancreatitis: Correlation with local and systemic complications. Am. J. Respir. Crit. Care Med. 2003, 168, 148-157. [CrossRef]

53. Perides, G.; Weiss, E.R.; Michael, E.S.; Laukkarinen, J.M.; Duffield, J.S.; Steer, M.L. TNF-alpha-dependent regulation of acute pancreatitis severity by Ly-6C(hi) monocytes in mice. J. Biol. Chem. 2011, 286, 13327-13335. [CrossRef] [PubMed]

54. Shamoon, M.; Deng, Y.; Chen, Y.Q.; Bhatia, M.; Sun, J. Therapeutic implications of innate immune system in acute pancreatitis. Expert Opin. Ther. Targets 2016, 20, 73-87. [CrossRef] [PubMed]

55. Xue, J.; Sharma, V.; Hsieh, M.H.; Chawla, A.; Murali, R.; Pandol, S.J.; Habtezion, A. Alternatively activated macrophages promote pancreatic fibrosis in chronic pancreatitis. Nat. Commun. 2015, 6, 7158. [CrossRef] [PubMed]

56. Storz, P. Acinar cell plasticity and development of pancreatic ductal adenocarcinoma. Nat. Rev. Gastroenterol. Hepatol. 2017, 14, 296-304. [CrossRef]

57. Song, S.Y.; Gannon, M.; Washington, M.K.; Scoggins, C.R.; Meszoely, I.M.; Goldenring, J.R.; Marino, C.R.; Sandgren, E.P.; Coffey, R.J., Jr.; Wright, C.V.; et al. Expansion of Pdx1-expressing pancreatic epithelium and islet neogenesis in transgenic mice overexpressing transforming growth factor alpha. Gastroenterology 1999, 117, 1416-1426. [CrossRef]

58. Stanger, B.Z.; Hebrok, M. Control of cell identity in pancreas development and regeneration. Gastroenterology 2013, 144, 1170-1179. [CrossRef]

59. Hingorani, S.R.; Wang, L.; Multani, A.S.; Combs, C.; Deramaudt, T.B.; Hruban, R.H.; Rustgi, A.K.; Chang, S.; Tuveson, D.A. Trp53R172H and KrasG12D cooperate to promote chromosomal instability and widely metastatic pancreatic ductal adenocarcinoma in mice. Cancer Cell 2005, 7, 469-483. [CrossRef] [PubMed]

60. Lee, J.W.; Komar, C.A.; Bengsch, F.; Graham, K.; Beatty, G.L. Genetically Engineered Mouse Models of Pancreatic Cancer: The KPC Model (LSL-Kras ${ }^{G 12 D /+} ; \mathrm{LSL}-\mathrm{Tr} p 53^{R 172 H /+} ; \mathrm{Pdx}$-1-Cre), Its Variants, and Their Application in Immuno-oncology Drug Discovery. Curr. Protoc. Pharmacol. 2016, 73, 14-39. [CrossRef] [PubMed]

61. Corcoran, R.B.; Contino, G.; Deshpande, V.; Tzatsos, A.; Conrad, C.; Benes, C.H.; Levy, D.E.; Settleman, J.; Engelman, J.A.; Bardeesy, N. STAT3 plays a critical role in KRAS-induced pancreatic tumorigenesis. Cancer Res. 2011, 71, 5020-5029. [CrossRef]

62. Ray, K.C.; Moss, M.E.; Franklin, J.L.; Weaver, C.J.; Higginbotham, J.; Song, Y.; Revetta, F.L.; Blaine, S.A.; Bridges, L.R.; Guess, K.E.; et al. Heparin-binding epidermal growth factor-like growth factor eliminates constraints on activated Kras to promote rapid onset of pancreatic neoplasia. Oncogene 2014, 33, 823-831. [CrossRef] [PubMed]

63. Kumar, S.; Torres, M.P.; Kaur, S.; Rachagani, S.; Joshi, S.; Johansson, S.L.; Momi, N.; Baine, M.J.; Gilling, C.E.; Smith, L.M.; et al. Smoking accelerates pancreatic cancer progression by promoting differentiation of MDSCs and inducing HB-EGF expression in macrophages. Oncogene 2015, 34, 2052-2060. [CrossRef]

64. Liou, G.-Y.; Bastea, L.; Fleming, A.; Döppler, H.; Edenfield, B.H.; Dawson, D.W.; Zhang, L.; Bardeesy, N.; Storz, P. The Presence of Interleukin-13 at Pancreatic ADM/PanIN Lesions Alters Macrophage Populations and Mediates Pancreatic Tumorigenesis. Cell Rep. 2017, 19, 1322-1333. [CrossRef] [PubMed]

65. Guerra, C.; Collado, M.; Navas, C.; Schuhmacher, A.J.; Hernández-Porras, I.; Cañamero, M.; Rodriguez-Justo, M.; Serrano, M.; Barbacid, M. Pancreatitis-induced inflammation contributes to pancreatic cancer by inhibiting oncogene-induced senescence. Cancer Cell 2011, 19, 728-739. [CrossRef]

66. Guerra, C.; Schuhmacher, A.J.; Cañamero, M.; Grippo, P.J.; Verdaguer, L.; Pérez-Gallego, L.; Dubus, P.; Sandgren, E.P.; Barbacid, M. Chronic pancreatitis is essential for induction of pancreatic ductal adenocarcinoma by K-Ras oncogenes in adult mice. Cancer Cell 2007, 11, 291-302. [CrossRef] [PubMed]

67. Rhim, A.D.; Mirek, E.T.; Aiello, N.M.; Maitra, A.; Bailey, J.M.; McAllister, F.; Reichert, M.; Beatty, G.L.; Rustgi, A.K.; Vonderheide, R.H.; et al. EMT and dissemination precede pancreatic tumor formation. Cell 2012, 148, 349-361. [CrossRef]

68. Rhim, A.D.; Thege, F.I.; Santana, S.M.; Lannin, T.B.; Saha, T.N.; Tsai, S.; Maggs, L.R.; Kochman, M.L.; Ginsberg, G.G.; Lieb, J.G.; et al. Detection of circulating pancreas epithelial cells in patients with pancreatic cystic lesions. Gastroenterology 2014, 146, 647-651. [CrossRef]

69. Lamouille, S.; Xu, J.; Derynck, R. Molecular mechanisms of epithelial-mesenchymal transition. Nat. Rev. Mol. Cell Biol. 2014, 15, 178-196. [CrossRef] 
70. Di Carlo, C.; Brandi, J.; Cecconi, D. Pancreatic cancer stem cells: Perspectives on potential therapeutic approaches of pancreatic ductal adenocarcinoma. World J. Stem Cells 2018, 10, 172-182. [CrossRef]

71. Valle, S.; Martin-Hijano, L.; Alcalá, S.; Alonso-Nocelo, M.; Sainz, B., Jr. The Ever-Evolving Concept of the Cancer Stem Cell in Pancreatic Cancer. Cancers 2018, 10, 33. [CrossRef]

72. Hou, Y.C.; Chao, Y.J.; Tung, H.L.; Wang, H.C.; Shan, Y.S. Coexpression of CD44-positive/CD133-positive cancer stem cells and CD204-positive tumor-associated macrophages is a predictor of survival in pancreatic ductal adenocarcinoma. Cancer 2014, 120, 2766-2777. [CrossRef] [PubMed]

73. Sainz, B., Jr.; Martín, B.; Tatari, M.; Heeschen, C.; Guerra, S. ISG15 is a critical microenvironmental factor for pancreatic cancer stem cells. Cancer Res. 2014, 74, 7309-7320. [CrossRef] [PubMed]

74. Sainz, B., Jr.; Alcala, S.; Garcia, E.; Sanchez-Ripoll, Y.; Azevedo, M.M.; Cioffi, M.; Tatari, M.; Miranda-Lorenzo, I.; Hidalgo, M.; Gomez-Lopez, G.; et al. Microenvironmental hCAP-18/LL-37 promotes pancreatic ductal adenocarcinoma by activating its cancer stem cell compartment. Gut 2015, 64, 1921-1935. [CrossRef] [PubMed]

75. Phillips, P.A.; McCarroll, J.A.; Park, S.; Wu, M.J.; Pirola, R.; Korsten, M.; Wilson, J.S.; Apte, M.V. Rat pancreatic stellate cells secrete matrix metalloproteinases: Implications for extracellular matrix turnover. Gut 2003, 52, 275-282. [CrossRef] [PubMed]

76. Apte, M.V.; Haber, P.S.; Darby, S.J.; Rodgers, S.C.; McCaughan, G.W.; Korsten, M.A.; Pirola, R.C.; Wilson, J.S. Pancreatic stellate cells are activated by proinflammatory cytokines: Implications for pancreatic fibrogenesis. Gut 1999, 44, 534-541. [CrossRef] [PubMed]

77. Mews, P.; Phillips, P.; Fahmy, R.; Korsten, M.; Pirola, R.; Wilson, J.; Apte, M. Pancreatic stellate cells respond to inflammatory cytokines: Potential role in chronic pancreatitis. Gut 2002, 50, 535-541. [CrossRef]

78. Schneider, E.; Schmid-Kotsas, A.; Zhao, J.; Weidenbach, H.; Schmid, R.M.; Menke, A.; Adler, G.; Waltenberger, J.; Grünert, A.; Bachem, M.G. Identification of mediators stimulating proliferation and matrix synthesis of rat pancreatic stellate cells. Am. J. Physiol. Cell Physiol. 2001, 281, C532-C543. [CrossRef] [PubMed]

79. Bachem, M.G.; Schünemann, M.; Ramadani, M.; Siech, M.; Beger, H.; Buck, A.; Zhou, S.; Schmid-Kotsas, A.; Adler, G. Pancreatic carcinoma cells induce fibrosis by stimulating proliferation and matrix synthesis of stellate cells. Gastroenterology 2005, 128, 907-921. [CrossRef] [PubMed]

80. Aoki, H.; Ohnishi, H.; Hama, K.; Ishijima, T.; Satoh, Y.; Hanatsuka, K.; Ohashi, A.; Wada, S.; Miyata, T.; Kita, H.; et al. Autocrine loop between TGF-beta1 and IL-1beta through Smad3- and ERK-dependent pathways in rat pancreatic stellate cells. Am. J. Physiol. Cell Physiol. 2006, 290, C1100-C1108. [CrossRef] [PubMed]

81. Kuen, J.; Darowski, D.; Kluge, T.; Majety, M. Pancreatic cancer cell/fibroblast co-culture induces M2 like macrophages that influence therapeutic response in a 3D model. PLoS ONE 2017, 12, e0182039. [CrossRef]

82. Zhang, A.; Qian, Y.; Ye, Z.; Chen, H.; Xie, H.; Zhou, L.; Shen, Y.; Zheng, S. Cancer-associated fibroblasts promote M2 polarization of macrophages in pancreatic ductal adenocarcinoma. Cancer Med. 2017, 6, 463-470. [CrossRef] [PubMed]

83. Andersson, P.; Yang, Y.; Hosaka, K.; Zhang, Y.; Fischer, C.; Braun, H.; Liu, S.; Yu, G.; Liu, S.; Beyaert, R.; et al. Molecular mechanisms of IL-33-mediated stromal interactions in cancer metastasis. JCI Insight 2018, 3. [CrossRef] [PubMed]

84. Shi, C.; Washington, M.K.; Chaturvedi, R.; Drosos, Y.; Revetta, F.L.; Weaver, C.J.; Buzhardt, E.; Yull, F.E.; Blackwell, T.S.; SosaPineda, B.; et al. Fibrogenesis in pancreatic cancer is a dynamic process regulated by macrophage-stellate cell interaction. Lab. Investig. 2014, 94, 409-421. [CrossRef]

85. Nielsen, S.R.; Quaranta, V.; Linford, A.; Emeagi, P.; Rainer, C.; Santos, A.; Ireland, L.; Sakai, T.; Sakai, K.; Kim, Y.S.; et al. Macrophage-secreted granulin supports pancreatic cancer metastasis by inducing liver fibrosis. Nat. Cell Biol. 2016, 18, 549-560. [CrossRef] [PubMed]

86. Kaneda, M.M.; Cappello, P.; Nguyen, A.V.; Ralainirina, N.; Hardamon, C.R.; Foubert, P.; Schmid, M.C.; Sun, P.; Mose, E.; Bouvet, M.; et al. Macrophage PI3K $\gamma$ Drives Pancreatic Ductal Adenocarcinoma Progression. Cancer Discov. 2016, 6, 870-885. [CrossRef]

87. Li, N.; Li, Y.; Li, Z.; Huang, C.; Yang, Y.; Lang, M.; Cao, J.; Jiang, W.; Xu, Y.; Dong, J.; et al. Hypoxia Inducible Factor 1 (HIF-1) Recruits Macrophage to Activate Pancreatic Stellate Cells in Pancreatic Ductal Adenocarcinoma. Int. J. Mol. Sci. 2016, 17, 799. [CrossRef]

88. Munn, D.H.; Sharma, M.D.; Baban, B.; Harding, H.P.; Zhang, Y.; Ron, D.; Mellor, A.L. GCN2 kinase in T cells mediates proliferative arrest and anergy induction in response to indoleamine 2,3-dioxygenase. Immunity 2005, 22, 633-642. [CrossRef] [PubMed]

89. Rodriguez, P.C.; Quiceno, D.G.; Ochoa, A.C. L-arginine availability regulates T-lymphocyte cell-cycle progression. Blood 2007, 109, 1568-1573. [CrossRef]

90. Rodriguez, P.C.; Zea, A.H.; DeSalvo, J.; Culotta, K.S.; Zabaleta, J.; Quiceno, D.G.; Ochoa, J.B.; Ochoa, A.C. L-arginine consumption by macrophages modulates the expression of CD3 zeta chain in T lymphocytes. J. Immunol. 2003, 171, 1232-1239. [CrossRef]

91. Rodriguez, P.C.; Quiceno, D.G.; Zabaleta, J.; Ortiz, B.; Zea, A.H.; Piazuelo, M.B.; Delgado, A.; Correa, P.; Brayer, J.; Sotomayor, E.M.; et al. Arginase I production in the tumor microenvironment by mature myeloid cells inhibits T-cell receptor expression and antigen-specific T-cell responses. Cancer Res. 2004, 64, 5839-5849. [CrossRef] [PubMed]

92. Kalinski, P. Regulation of immune responses by prostaglandin E2. J. Immunol. 2012, 188, 21-28. [CrossRef] [PubMed]

93. Oh, S.A.; Li, M.O. TGF- $\beta$ : Guardian of T cell function. J. Immunol. 2013, 191, 3973-3979. [CrossRef] [PubMed]

94. Ruffell, B.; Chang-Strachan, D.; Chan, V.; Rosenbusch, A.; Ho, C.M.; Pryer, N.; Daniel, D.; Hwang, E.S.; Rugo, H.S.; Coussens, L.M. Macrophage IL-10 blocks CD8+ T cell-dependent responses to chemotherapy by suppressing IL-12 expression in intratumoral dendritic cells. Cancer Cell 2014, 26, 623-637. [CrossRef] 
95. Balkwill, F. Cancer and the chemokine network. Nat. Rev. Cancer 2004, 4, 540-550. [CrossRef]

96. Sica, A.; Saccani, A.; Bottazzi, B.; Polentarutti, N.; Vecchi, A.; van Damme, J.; Mantovani, A. Autocrine production of IL-10 mediates defective IL-12 production and NF-kappa B activation in tumor-associated macrophages. J. Immunol. 2000, 164, 762-767. [CrossRef]

97. Parihar, R.; Dierksheide, J.; Hu, Y.; Carson, W.E. IL-12 enhances the natural killer cell cytokine response to Ab-coated tumor cells. J. Clin. Investig. 2002, 110, 983-992. [CrossRef] [PubMed]

98. Krneta, T.; Gillgrass, A.; Poznanski, S.; Chew, M.; Lee, A.J.; Kolb, M.; Ashkar, A.A. M2-polarized and tumor-associated macrophages alter NK cell phenotype and function in a contact-dependent manner. J. Leukoc. Biol. 2017, 101, 285-295. [CrossRef]

99. Kuang, D.M.; Zhao, Q.; Peng, C.; Xu, J.; Zhang, J.P.; Wu, C.; Zheng, L. Activated monocytes in peritumoral stroma of hepatocellular carcinoma foster immune privilege and disease progression through PD-L1. J. Exp. Med. 2009, 206, 1327-1337. [CrossRef]

100. Ojalvo, L.S.; King, W.; Cox, D.; Pollard, J.W. High-density gene expression analysis of tumor-associated macrophages from mouse mammary tumors. Am. J. Pathol. 2009, 174, 1048-1064. [CrossRef]

101. Daley, D.; Mani, V.R.; Mohan, N.; Akkad, N.; Ochi, A.; Heindel, D.W.; Lee, K.B.; Zambirinis, C.P.; Pandian, G.S.B.; Savadkar, S.; et al. Dectin 1 activation on macrophages by galectin 9 promotes pancreatic carcinoma and peritumoral immune tolerance. Nat. Med. 2017, 23, 556-567. [CrossRef] [PubMed]

102. Daley, D.; Mani, V.R.; Mohan, N.; Akkad, N.; Pandian, G.; Savadkar, S.; Lee, K.B.; Torres-Hernandez, A.; Aykut, B.; Diskin, B.; et al. NLRP3 signaling drives macrophage-induced adaptive immune suppression in pancreatic carcinoma. J. Exp. Med. 2017, 214, 1711-1724. [CrossRef] [PubMed]

103. Savage, N.D.; de Boer, T.; Walburg, K.V.; Joosten, S.A.; van Meijgaarden, K.; Geluk, A.; Ottenhoff, T.H. Human anti-inflammatory macrophages induce Foxp $3^{+} \mathrm{GITR}^{+} \mathrm{CD} 25^{+}$regulatory T cells, which suppress via membrane-bound TGFbeta-1. J. Immunol. 2008, 181, 2220-2226. [CrossRef]

104. Büchler, P.; Reber, H.A.; Büchler, M.; Shrinkante, S.; Büchler, M.W.; Friess, H.; Semenza, G.L.; Hines, O.J. Hypoxia-inducible factor 1 regulates vascular endothelial growth factor expression in human pancreatic cancer. Pancreas 2003, 26, 56-64. [CrossRef]

105. Shibaji, T.; Nagao, M.; Ikeda, N.; Kanehiro, H.; Hisanaga, M.; Ko, S.; Fukumoto, A.; Nakajima, Y. Prognostic significance of HIF-1 alpha overexpression in human pancreatic cancer. Anticancer Res. 2003, 23, 4721-4727.

106. Itakura, J.; Ishiwata, T.; Friess, H.; Fujii, H.; Matsumoto, Y.; Büchler, M.W.; Korc, M. Enhanced expression of vascular endothelial growth factor in human pancreatic cancer correlates with local disease progression. Clin. Cancer Res. 1997, 3, 1309-1316.

107. De Palma, M.; Lewis, C.E. Macrophage regulation of tumor responses to anticancer therapies. Cancer Cell 2013, 23, 277-286. [CrossRef]

108. Yang, Y.; Guo, Z.; Chen, W.; Wang, X.; Cao, M.; Han, X.; Zhang, K.; Teng, B.; Cao, J.; Wu, W.; et al. M2 Macrophage-Derived Exosomes Promote Angiogenesis and Growth of Pancreatic Ductal Adenocarcinoma by Targeting E2F2. Mol. Ther. 2021, 29, 1226-1238. [CrossRef] [PubMed]

109. Huang, C.; Li, Z.; Li, N.; Li, Y.; Chang, A.; Zhao, T.; Wang, X.; Wang, H.; Gao, S.; Yang, S.; et al. Interleukin 35 Expression Correlates With Microvessel Density in Pancreatic Ductal Adenocarcinoma, Recruits Monocytes, and Promotes Growth and Angiogenesis of Xenograft Tumors in Mice. Gastroenterology 2018, 154, 675-688. [CrossRef] [PubMed]

110. Atanasov, G.; Pötner, C.; Aust, G.; Schierle, K.; Dietel, C.; Benzing, C.; Krenzien, F.; Bartels, M.; Eichfeld, U.; Schmelzle, M.; et al. TIE2-expressing monocytes and M2-polarized macrophages impact survival and correlate with angiogenesis in adenocarcinoma of the pancreas. Oncotarget 2018, 9, 29715-29726. [CrossRef]

111. Murdoch, C.; Tazzyman, S.; Webster, S.; Lewis, C.E. Expression of Tie-2 by human monocytes and their responses to angiopoietin-2. J. Immunol. 2007, 178, 7405-7411. [CrossRef]

112. Venneri, M.A.; De Palma, M.; Ponzoni, M.; Pucci, F.; Scielzo, C.; Zonari, E.; Mazzieri, R.; Doglioni, C.; Naldini, L. Identification of proangiogenic TIE2-expressing monocytes (TEMs) in human peripheral blood and cancer. Blood 2007, 109, 5276-5285. [CrossRef] [PubMed]

113. Kurahara, H.; Takao, S.; Shinchi, H.; Maemura, K.; Mataki, Y.; Sakoda, M.; Hayashi, T.; Kuwahata, T.; Minami, K.; Ueno, S.; et al. Significance of lymphangiogenesis in primary tumor and draining lymph nodes during lymphatic metastasis of pancreatic head cancer. J. Surg. Oncol. 2010, 102, 809-815. [CrossRef]

114. Wang, Z.; Wu, J.; Li, G.; Zhang, X.; Tong, M.; Wu, Z.; Liu, Z. Lymphangiogenesis and biological behavior in pancreatic carcinoma and other pancreatic tumors. Mol. Med. Rep. 2012, 5, 959-963. [CrossRef]

115. Riabov, V.; Gudima, A.; Wang, N.; Mickley, A.; Orekhov, A.; Kzhyshkowska, J. Role of tumor associated macrophages in tumor angiogenesis and lymphangiogenesis. Front. Physiol. 2014, 5, 75. [CrossRef] [PubMed]

116. Alishekevitz, D.; Gingis-Velitski, S.; Kaidar-Person, O.; Gutter-Kapon, L.; Scherer, S.D.; Raviv, Z.; Merquiol, E.; Ben-Nun, Y.; Miller, V.; Rachman-Tzemah, C.; et al. Macrophage-Induced Lymphangiogenesis and Metastasis following Paclitaxel Chemotherapy Is Regulated by VEGFR3. Cell Rep. 2016, 17, 1344-1356. [CrossRef]

117. Scavelli, C.; Vacca, A.; Di Pietro, G.; Dammacco, F.; Ribatti, D. Crosstalk between angiogenesis and lymphangiogenesis in tumor progression. Leukemia 2004, 18, 1054-1058. [CrossRef] [PubMed]

118. Coffelt, S.B.; Hughes, R.; Lewis, C.E. Tumor-associated macrophages: Effectors of angiogenesis and tumor progression. Biochim. Biophys. Acta 2009, 1796, 11-18. [CrossRef] [PubMed]

119. Gomes, F.G.; Nedel, F.; Alves, A.M.; Nör, J.E.; Tarquinio, S.B. Tumor angiogenesis and lymphangiogenesis: Tumor/endothelial crosstalk and cellular/microenvironmental signaling mechanisms. Life Sci. 2013, 92, 101-107. [CrossRef] 
120. Kurahara, H.; Shinchi, H.; Mataki, Y.; Maemura, K.; Noma, H.; Kubo, F.; Sakoda, M.; Ueno, S.; Natsugoe, S.; Takao, S. Significance of M2-polarized tumor-associated macrophage in pancreatic cancer. J. Surg. Res. 2011, 167, e211-e219. [CrossRef] [PubMed]

121. Kurahara, H.; Takao, S.; Kuwahata, T.; Nagai, T.; Ding, Q.; Maeda, K.; Shinchi, H.; Mataki, Y.; Maemura, K.; Matsuyama, T.; et al. Clinical significance of folate receptor $\beta$-expressing tumor-associated macrophages in pancreatic cancer. Ann. Surg. Oncol. 2012, 19, 2264-2271. [CrossRef]

122. Quail, D.F.; Joyce, J.A. Microenvironmental regulation of tumor progression and metastasis. Nat. Med. 2013, 19, 1423-1437. [CrossRef] [PubMed]

123. Yachida, S.; Iacobuzio-Donahue, C.A. The pathology and genetics of metastatic pancreatic cancer. Arch. Pathol. Lab. Med. 2009, 133, 413-422. [CrossRef]

124. Chen, Q.; Wang, J.; Zhang, Q.; Zhang, J.; Lou, Y.; Yang, J.; Chen, Y.; Wei, T.; Zhang, J.; Fu, Q.; et al. Tumour cell-derived debris and IgG synergistically promote metastasis of pancreatic cancer by inducing inflammation via tumour-associated macrophages. $\mathrm{Br}$. $\mathrm{J}$. Cancer 2019, 121, 786-795. [CrossRef]

125. Meng, F.; Li, W.; Li, C.; Gao, Z.; Guo, K.; Song, S. CCL18 promotes epithelial-mesenchymal transition, invasion and migration of pancreatic cancer cells in pancreatic ductal adenocarcinoma. Int. J. Oncol. 2015, 46, 1109-1120. [CrossRef]

126. Chen, S.J.; Lian, G.D.; Li, J.J.; Zhang, Q.B.; Zeng, L.J.; Yang, K.G.; Huang, C.M.; Li, Y.Q.; Chen, Y.T.; Huang, K.H. Tumor-driven like macrophages induced by conditioned media from pancreatic ductal adenocarcinoma promote tumor metastasis via secreting IL-8. Cancer Med. 2018, 7, 5679-5690. [CrossRef] [PubMed]

127. Tekin, C.; Aberson, H.L.; Waasdorp, C.; Hooijer, G.K.J.; de Boer, O.J.; Dijk, F.; Bijlsma, M.F.; Spek, C.A. Macrophage-secreted MMP9 induces mesenchymal transition in pancreatic cancer cells via PAR1 activation. Cell. Oncol. 2020, 43, 1161-1174. [CrossRef] [PubMed]

128. Liu, C.-Y.; Xu, J.-Y.; Shi, X.-Y.; Huang, W.; Ruan, T.-Y.; Xie, P.; Ding, J.-L. M2-polarized tumor-associated macrophages promoted epithelial-mesenchymal transition in pancreatic cancer cells, partially through TLR4/IL-10 signaling pathway. Lab. Investig. 2013, 93, 844-854. [CrossRef]

129. Ye, H.; Zhou, Q.; Zheng, S.; Li, G.; Lin, Q.; Wei, L.; Fu, Z.; Zhang, B.; Liu, Y.; Li, Z.; et al. Tumor-associated macrophages promote progression and the Warburg effect via CCL18/NF-kB/VCAM-1 pathway in pancreatic ductal adenocarcinoma. Cell Death Dis. 2018, 9, 453. [CrossRef]

130. Kaplan, R.N.; Riba, R.D.; Zacharoulis, S.; Bramley, A.H.; Vincent, L.; Costa, C.; MacDonald, D.D.; Jin, D.K.; Shido, K.; Kerns, S.A.; et al. VEGFR1-positive haematopoietic bone marrow progenitors initiate the pre-metastatic niche. Nature 2005, 438, 820-827. [CrossRef]

131. Sceneay, J.; Smyth, M.J.; Möller, A. The pre-metastatic niche: Finding common ground. Cancer Metastasis Rev. 2013, 32, 449-464. [CrossRef]

132. Joyce, J.A.; Pollard, J.W. Microenvironmental regulation of metastasis. Nat. Rev. Cancer 2009, 9, 239-252. [CrossRef]

133. Costa-Silva, B.; Aiello, N.M.; Ocean, A.J.; Singh, S.; Zhang, H.; Thakur, B.K.; Becker, A.; Hoshino, A.; Mark, M.T.; Molina, H.; et al. Pancreatic cancer exosomes initiate pre-metastatic niche formation in the liver. Nat. Cell Biol. 2015, 17, 816-826. [CrossRef]

134. Quiñonero, F.; Mesas, C.; Doello, K.; Cabeza, L.; Perazzoli, G.; Jimenez-Luna, C.; Rama, A.R.; Melguizo, C.; Prados, J. The challenge of drug resistance in pancreatic ductal adenocarcinoma: A current overview. Cancer Biol. Med. $2019,16,688-699$. [CrossRef]

135. Kuwada, K.; Kagawa, S.; Yoshida, R.; Sakamoto, S.; Ito, A.; Watanabe, M.; Ieda, T.; Kuroda, S.; Kikuchi, S.; Tazawa, H.; et al. The epithelial-to-mesenchymal transition induced by tumor-associated macrophages confers chemoresistance in peritoneally disseminated pancreatic cancer. J. Exp. Clin. Cancer Res. 2018, 37, 307. [CrossRef]

136. Weizman, N.; Krelin, Y.; Shabtay-Orbach, A.; Amit, M.; Binenbaum, Y.; Wong, R.J.; Gil, Z. Macrophages mediate gemcitabine resistance of pancreatic adenocarcinoma by upregulating cytidine deaminase. Oncogene 2014, 33, 3812-3819. [CrossRef] [PubMed]

137. Buchholz, S.M.; Goetze, R.G.; Singh, S.K.; Ammer-Herrmenau, C.; Richards, F.M.; Jodrell, D.I.; Buchholz, M.; Michl, P.; Ellenrieder, V.; Hessmann, E.; et al. Depletion of Macrophages Improves Therapeutic Response to Gemcitabine in Murine Pancreas Cancer. Cancers 2020, 12, 1978. [CrossRef]

138. Ireland, L.; Santos, A.; Ahmed, M.S.; Rainer, C.; Nielsen, S.R.; Quaranta, V.; Weyer-Czernilofsky, U.; Engle, D.D.; Perez-Mancera, P.A.; Coupland, S.E.; et al. Chemoresistance in Pancreatic Cancer Is Driven by Stroma-Derived Insulin-Like Growth Factors. Cancer Res. 2016, 76, 6851-6863. [CrossRef] [PubMed]

139. Zhang, M.; Yan, L.; Wang, G.J.; Jin, R. Resistin effects on pancreatic cancer progression and chemoresistance are mediated through its receptors CAP1 and TLR4. J. Cell. Physiol. 2019, 234, 9457-9466. [CrossRef]

140. Michaels, A.D.; Newhook, T.E.; Adair, S.J.; Morioka, S.; Goudreau, B.J.; Nagdas, S.; Mullen, M.G.; Persily, J.B.; Bullock, T.N.J.; Slingluff, C.L., Jr.; et al. CD47 Blockade as an Adjuvant Immunotherapy for Resectable Pancreatic Cancer. Cli. Cancer Res. Off. J. Am. Assoc. Cancer Res. 2018, 24, 1415-1425. [CrossRef] [PubMed]

141. Germano, G.; Frapolli, R.; Belgiovine, C.; Anselmo, A.; Pesce, S.; Liguori, M.; Erba, E.; Uboldi, S.; Zucchetti, M.; Pasqualini, F.; et al. Role of macrophage targeting in the antitumor activity of trabectedin. Cancer Cell 2013, 23, 249-262. [CrossRef] [PubMed]

142. Borgoni, S.; Iannello, A.; Cutrupi, S.; Allavena, P.; D'Incalci, M.; Novelli, F.; Cappello, P. Depletion of tumor-associated macrophages switches the epigenetic profile of pancreatic cancer infiltrating $\mathrm{T}$ cells and restores their anti-tumor phenotype. Oncoimmunology 2018, 7, e1393596. [CrossRef] 
143. Céspedes, M.V.; Guillén, M.J.; López-Casas, P.P.; Sarno, F.; Gallardo, A.; Álamo, P.; Cuevas, C.; Hidalgo, M.; Galmarini, C.M.; Allavena, P.; et al. Lurbinectedin induces depletion of tumor-associated macrophages, an essential component of its in vivo synergism with gemcitabine, in pancreatic adenocarcinoma mouse models. Dis. Models Mech. 2016, 9, 1461-1471. [CrossRef]

144. Stanley, E.R.; Chitu, V. CSF-1 receptor signaling in myeloid cells. Cold Spring Harb. Perspect. Biol. 2014, 6, a021857. [CrossRef]

145. Candido, J.B.; Morton, J.P.; Bailey, P.; Campbell, A.D.; Karim, S.A.; Jamieson, T.; Lapienyte, L.; Gopinathan, A.; Clark, W.; McGhee, E.J.; et al. CSF1R+ Macrophages Sustain Pancreatic Tumor Growth through T Cell Suppression and Maintenance of Key Gene Programs that Define the Squamous Subtype. Cell Rep. 2018, 23, 1448-1460. [CrossRef]

146. Zhu, Y.; Knolhoff, B.L.; Meyer, M.A.; Nywening, T.M.; West, B.L.; Luo, J.; Wang-Gillam, A.; Goedegebuure, S.P.; Linehan, D.C.; DeNardo, D.G. CSF1/CSF1R blockade reprograms tumor-infiltrating macrophages and improves response to T-cell checkpoint immunotherapy in pancreatic cancer models. Cancer Res. 2014, 74, 5057-5069. [CrossRef] [PubMed]

147. Jones, K.I.; Tiersma, J.; Yuzhalin, A.E.; Gordon-Weeks, A.N.; Buzzelli, J.; Im, J.H.; Muschel, R.J. Radiation combined with macrophage depletion promotes adaptive immunity and potentiates checkpoint blockade. EMBO Mol. Med. 2018, 10. [CrossRef]

148. Saung, M.T.; Muth, S.; Ding, D.; Thomas, D.L., 2nd; Blair, A.B.; Tsujikawa, T.; Coussens, L.; Jaffee, E.M.; Zheng, L. Targeting myeloid-inflamed tumor with anti-CSF-1R antibody expands CD137+ effector T-cells in the murine model of pancreatic cancer. J. Immunother. Cancer 2018, 6, 118. [CrossRef]

149. Nywening, T.M.; Wang-Gillam, A.; Sanford, D.E.; Belt, B.A.; Panni, R.Z.; Cusworth, B.M.; Toriola, A.T.; Nieman, R.K.; Worley, L.A.; Yano, M.; et al. Targeting tumour-associated macrophages with CCR2 inhibition in combination with FOLFIRINOX in patients with borderline resectable and locally advanced pancreatic cancer: A single-centre, open-label, dose-finding, non-randomised, phase $1 \mathrm{~b}$ trial. Lancet Oncol. 2016, 17, 651-662. [CrossRef]

150. Linehan, D.; Noel, M.S.; Hezel, A.F.; Wang-Gillam, A.; Eskens, F.; Sleijfer, S.; Desar, I.M.E.; Erdkamp, F.; Wilmink, J.; Diehl, J.; et al. Overall survival in a trial of orally administered CCR2 inhibitor CCX872 in locally advanced/metastatic pancreatic cancer: Correlation with blood monocyte counts. J. Clin. Oncol. 2018, 36, 92. [CrossRef]

151. Kaneda, M.M.; Messer, K.S.; Ralainirina, N.; Li, H.; Leem, C.J.; Gorjestani, S.; Woo, G.; Nguyen, A.V.; Figueiredo, C.C.; Foubert, P.; et al. PI3K $\gamma$ is a molecular switch that controls immune suppression. Nature 2016, 539, 437-442. [CrossRef]

152. Schmid, M.C.; Avraamides, C.J.; Dippold, H.C.; Franco, I.; Foubert, P.; Ellies, L.G.; Acevedo, L.M.; Manglicmot, J.R.; Song, X.; Wrasidlo, W.; et al. Receptor tyrosine kinases and TLR/IL1Rs unexpectedly activate myeloid cell PI3k $\gamma$, a single convergent point promoting tumor inflammation and progression. Cancer Cell 2011, 19, 715-727. [CrossRef]

153. Gunderson, A.J.; Kaneda, M.M.; Tsujikawa, T.; Nguyen, A.V.; Affara, N.I.; Ruffell, B.; Gorjestani, S.; Liudahl, S.M.; Truitt, M.; Olson, P.; et al. Bruton Tyrosine Kinase-Dependent Immune Cell Cross-talk Drives Pancreas Cancer. Cancer Discov. 2016, 6, 270-285. [CrossRef]

154. Ueta, T.; Ishihara, K.; Notomi, S.; Lee, J.-J.; Maidana, D.E.; Efstathiou, N.E.; Murakami, Y.; Hasegawa, E.; Azuma, K.; Toyono, T.; et al. RIP1 kinase mediates angiogenesis by modulating macrophages in experimental neovascularization. Proc. Natl. Acad. Sci. USA 2019, 116, 23705. [CrossRef] [PubMed]

155. Wang, W.; Marinis, J.M.; Beal, A.M.; Savadkar, S.; Wu, Y.; Khan, M.; Taunk, P.S.; Wu, N.; Su, W.; Wu, J.; et al. RIP1 Kinase Drives Macrophage-Mediated Adaptive Immune Tolerance in Pancreatic Cancer. Cancer Cell 2018, 34, 757-774. [CrossRef] [PubMed]

156. Bennett, S.R.; Carbone, F.R.; Karamalis, F.; Flavell, R.A.; Miller, J.F.; Heath, W.R. Help for cytotoxic-T-cell responses is mediated by CD40 signalling. Nature 1998, 393, 478-480. [CrossRef] [PubMed]

157. Hernandez, M.G.; Shen, L.; Rock, K.L. CD40 on APCs is needed for optimal programming, maintenance, and recall of CD8 ${ }^{+} \mathrm{T}$ cell memory even in the absence of $\mathrm{CD}^{+} \mathrm{T}$ cell help. J. Immunol. 2008, 180, 4382-4390. [CrossRef] [PubMed]

158. Beatty, G.L.; Chiorean, E.G.; Fishman, M.P.; Saboury, B.; Teitelbaum, U.R.; Sun, W.; Huhn, R.D.; Song, W.; Li, D.; Sharp, L.L.; et al. CD40 agonists alter tumor stroma and show efficacy against pancreatic carcinoma in mice and humans. Science 2011, 331, 1612-1616. [CrossRef]

159. Byrne, K.T.; Vonderheide, R.H. CD40 Stimulation Obviates Innate Sensors and Drives T Cell Immunity in Cancer. Cell Rep. 2016, 15, 2719-2732. [CrossRef]

160. Stromnes, I.M.; Burrack, A.L.; Hulbert, A.; Bonson, P.; Black, C.; Brockenbrough, J.S.; Raynor, J.F.; Spartz, E.J.; Pierce, R.H.; Greenberg, P.D.; et al. Differential Effects of Depleting versus Programming Tumor-Associated Macrophages on Engineered T Cells in Pancreatic Ductal Adenocarcinoma. Cancer Immunol. Res. 2019, 7, 977-989. [CrossRef]

161. Ma, H.S.; Poudel, B.; Torres, E.R.; Sidhom, J.W.; Robinson, T.M.; Christmas, B.; Scott, B.; Cruz, K.; Woolman, S.; Wall, V.Z.; et al. A CD40 Agonist and PD-1 Antagonist Antibody Reprogram the Microenvironment of Nonimmunogenic Tumors to Allow T-cell-Mediated Anticancer Activity. Cancer Immunol. Res. 2019, 7, 428-442. [CrossRef]

162. O'Hara, M.H.; O’Reilly, E.M.; Varadhachary, G.; Wolff, R.A.; Wainberg, Z.A.; Ko, A.H.; Fisher, G.; Rahma, O.; Lyman, J.P.; Cabanski, C.R.; et al. CD40 agonistic monoclonal antibody APX005M (sotigalimab) and chemotherapy, with or without nivolumab, for the treatment of metastatic pancreatic adenocarcinoma: An open-label, multicentre, phase 1b study. Lancet Oncol. 2021, 22, 118-131. [CrossRef]

163. Gahmberg, C.G. Leukocyte adhesion: CD11/CD18 integrins and intercellular adhesion molecules. Curr. Opin. Cell Biol. 1997, 9, 643-650. [CrossRef]

164. Sica, A.; Mantovani, A. Macrophage plasticity and polarization: In vivo veritas. J. Clin. Investig. 2012, 122, 787-795. [CrossRef] [PubMed] 
165. Maiguel, D.; Faridi, M.H.; Wei, C.; Kuwano, Y.; Balla, K.M.; Hernandez, D.; Barth, C.J.; Lugo, G.; Donnelly, M.; Nayer, A.; et al. Small molecule-mediated activation of the integrin CD11b/CD18 reduces inflammatory disease. Sci. Signal. 2011,4 , ra57. [CrossRef] [PubMed]

166. Panni, R.Z.; Herndon, J.M.; Zuo, C.; Hegde, S.; Hogg, G.D.; Knolhoff, B.L.; Breden, M.A.; Li, X.; Krisnawan, V.E.; Khan, S.Q.; et al. Agonism of CD11b reprograms innate immunity to sensitize pancreatic cancer to immunotherapies. Sci. Transl. Med. 2019, 11. [CrossRef] [PubMed]

167. Jaiswal, S.; Jamieson, C.H.; Pang, W.W.; Park, C.Y.; Chao, M.P.; Majeti, R.; Traver, D.; van Rooijen, N.; Weissman, I.L. CD47 is upregulated on circulating hematopoietic stem cells and leukemia cells to avoid phagocytosis. Cell 2009, 138, 271-285. [CrossRef]

168. Sick, E.; Jeanne, A.; Schneider, C.; Dedieu, S.; Takeda, K.; Martiny, L. CD47 update: A multifaceted actor in the tumour microenvironment of potential therapeutic interest. Br. J. Pharmacol. 2012, 167, 1415-1430. [CrossRef]

169. Cioffi, M.; Trabulo, S.; Hidalgo, M.; Costello, E.; Greenhalf, W.; Erkan, M.; Kleeff, J.; Sainz, B., Jr.; Heeschen, C. Inhibition of CD47 Effectively Targets Pancreatic Cancer Stem Cells via Dual Mechanisms. Clin. Cancer Res. 2015, 21, 2325-2337. [CrossRef]

170. Kamerkar, S.; LeBleu, V.S.; Sugimoto, H.; Yang, S.; Ruivo, C.F.; Melo, S.A.; Lee, J.J.; Kalluri, R. Exosomes facilitate therapeutic targeting of oncogenic KRAS in pancreatic cancer. Nature 2017, 546, 498-503. [CrossRef]

171. Pan, Y.; Lu, F.; Fei, Q.; Yu, X.; Xiong, P.; Yu, X.; Dang, Y.; Hou, Z.; Lin, W.; Lin, X.; et al. Single-cell RNA sequencing reveals compartmental remodeling of tumor-infiltrating immune cells induced by anti-CD47 targeting in pancreatic cancer. J. Hematol. Oncol. 2019, 12, 124. [CrossRef]

172. Xi, Q.; Chen, Y.; Yang, G.Z.; Zhang, J.Y.; Zhang, L.J.; Guo, X.D.; Zhao, J.Y.; Xue, Z.Y.; Li, Y.; Zhang, R. miR-128 Regulates Tumor Cell CD47 Expression and Promotes Anti-tumor Immunity in Pancreatic Cancer. Front. Immunol. 2020, 11, 890. [CrossRef] [PubMed]

173. Xi, Q.; Zhang, J.; Yang, G.; Zhang, L.; Chen, Y.; Wang, C.; Zhang, Z.; Guo, X.; Zhao, J.; Xue, Z.; et al. Restoration of miR-340 controls pancreatic cancer cell CD47 expression to promote macrophage phagocytosis and enhance antitumor immunity. J. Immunother. Cancer 2020, 8, e000253. [CrossRef]

174. El Chartouni, C.; Schwarzfischer, L.; Rehli, M. Interleukin-4 induced interferon regulatory factor (Irf) 4 participates in the regulation of alternative macrophage priming. Immunobiology 2010, 215, 821-825. [CrossRef]

175. Lawrence, T.; Natoli, G. Transcriptional regulation of macrophage polarization: Enabling diversity with identity. Nat. Rev. Immunol. 2011, 11, 750-761. [CrossRef]

176. Satoh, T.; Takeuchi, O.; Vandenbon, A.; Yasuda, K.; Tanaka, Y.; Kumagai, Y.; Miyake, T.; Matsushita, K.; Okazaki, T.; Saitoh, T.; et al. The Jmjd3-Irf4 axis regulates M2 macrophage polarization and host responses against helminth infection. Nat. Immunol. 2010, 11, 936-944. [CrossRef] [PubMed]

177. Bastea, L.I.; Liou, G.-Y.; Pandey, V.; Fleming, A.K.; von Roemeling, C.A.; Doeppler, H.; Li, Z.; Qiu, Y.; Edenfield, B.; Copland, J.A.; et al. Pomalidomide Alters Pancreatic Macrophage Populations to Generate an Immune-Responsive Environment at Precancerous and Cancerous Lesions. Cancer Res. 2019, 79, 1535-1548. [CrossRef]

178. Shirai, Y.; Saito, N.; Uwagawa, T.; Shiba, H.; Horiuchi, T.; Iwase, R.; Haruki, K.; Ohashi, T.; Yanaga, K. Pomalidomide promotes chemosensitization of pancreatic cancer by inhibition of NF-kB. Oncotarget 2018, 9, 15292-15301. [CrossRef] [PubMed]

179. De Palma, M.; Venneri, M.A.; Galli, R.; Sergi Sergi, L.; Politi, L.S.; Sampaolesi, M.; Naldini, L. Tie2 identifies a hematopoietic lineage of proangiogenic monocytes required for tumor vessel formation and a mesenchymal population of pericyte progenitors. Cancer Cell 2005, 8, 211-226. [CrossRef]

180. Harney, A.S.; Karagiannis, G.S.; Pignatelli, J.; Smith, B.D.; Kadioglu, E.; Wise, S.C.; Hood, M.M.; Kaufman, M.D.; Leary, C.B.; Lu, W.P.; et al. The Selective Tie2 Inhibitor Rebastinib Blocks Recruitment and Function of Tie2(Hi) Macrophages in Breast Cancer and Pancreatic Neuroendocrine Tumors. Mol. Cancer Ther. 2017, 16, 2486-2501. [CrossRef]

181. Ho, W.J.; Jaffee, E.M.; Zheng, L. The tumour microenvironment in pancreatic cancer-Clinical challenges and opportunities. Nat. Rev. Clin. Oncol. 2020, 17, 527-540. [CrossRef]

182. Mestas, J.; Hughes, C.C. Of mice and not men: Differences between mouse and human immunology. J. Immunol. 2004, 172, 2731-2738. [CrossRef]

183. Austyn, J.M.; Gordon, S. F4/80, a monoclonal antibody directed specifically against the mouse macrophage. Eur. J. Immunol. 1981, 11, 805-815. [CrossRef] [PubMed]

184. Ruffell, B.; Coussens, L.M. Macrophages and therapeutic resistance in cancer. Cancer Cell 2015, 27, 462-472. [CrossRef]

185. Hart, P.H.; Bonder, C.S.; Balogh, J.; Dickensheets, H.L.; Donnelly, R.P.; Finlay-Jones, J.J. Differential responses of human monocytes and macrophages to IL-4 and IL-13. J. Leukoc. Biol. 1999, 66, 575-578. [CrossRef] [PubMed]

186. Whatcott, C.J.; Diep, C.H.; Jiang, P.; Watanabe, A.; LoBello, J.; Sima, C.; Hostetter, G.; Shepard, H.M.; Von Hoff, D.D.; Han, H. Desmoplasia in Primary Tumors and Metastatic Lesions of Pancreatic Cancer. Clin. Cancer Res. 2015, 21, 3561-3568. [CrossRef] [PubMed]

187. Ligorio, M.; Sil, S.; Malagon-Lopez, J.; Nieman, L.T.; Misale, S.; Di Pilato, M.; Ebright, R.Y.; Karabacak, M.N.; Kulkarni, A.S.; Liu, A.; et al. Stromal Microenvironment Shapes the Intratumoral Architecture of Pancreatic Cancer. Cell 2019, 178, 160-175.e127. [CrossRef]

188. Machiels, J.P.; Gomez-Roca, C.; Michot, J.M.; Zamarin, D.; Mitchell, T.; Catala, G.; Eberst, L.; Jacob, W.; Jegg, A.M.; Cannarile, M.A.; et al. Phase Ib study of anti-CSF-1R antibody emactuzumab in combination with CD40 agonist selicrelumab in advanced solid tumor patients. J. Immunother. Cancer 2020, 8, e001153. [CrossRef] 
189. Papadopoulos, K.P.; Gluck, L.; Martin, L.P.; Olszanski, A.J.; Tolcher, A.W.; Ngarmchamnanrith, G.; Rasmussen, E.; Amore, B.M.; Nagorsen, D.; Hill, J.S.; et al. First-in-Human Study of AMG 820, a Monoclonal Anti-Colony-Stimulating Factor 1 Receptor Antibody, in Patients with Advanced Solid Tumors. Clin.Cancer Res. 2017, 23, 5703. [CrossRef]

190. Soares, K.C.; Foley, K.; Olino, K.; Leubner, A.; Mayo, S.C.; Jain, A.; Jaffee, E.; Schulick, R.D.; Yoshimura, K.; Edil, B.; et al. A preclinical murine model of hepatic metastases. J. Vis. Exp. 2014, 51677. [CrossRef]

191. Wu, K.; Lin, K.; Li, X.; Yuan, X.; Xu, P.; Ni, P.; Xu, D. Redefining Tumor-Associated Macrophage Subpopulations and Functions in the Tumor Microenvironment. Front. Immunol. 2020, 11, 1731. [CrossRef]

192. Collisson, E.A.; Sadanandam, A.; Olson, P.; Gibb, W.J.; Truitt, M.; Gu, S.; Cooc, J.; Weinkle, J.; Kim, G.E.; Jakkula, L.; et al. Subtypes of pancreatic ductal adenocarcinoma and their differing responses to therapy. Nat. Med. 2011, 17, 500-503. [CrossRef]

193. Moffitt, R.A.; Marayati, R.; Flate, E.L.; Volmar, K.E.; Loeza, S.G.; Hoadley, K.A.; Rashid, N.U.; Williams, L.A.; Eaton, S.C.; Chung, A.H.; et al. Virtual microdissection identifies distinct tumor- and stroma-specific subtypes of pancreatic ductal adenocarcinoma. Nat. Genet. 2015, 47, 1168-1178. [CrossRef]

194. Bailey, P.; Chang, D.K.; Nones, K.; Johns, A.L.; Patch, A.M.; Gingras, M.C.; Miller, D.K.; Christ, A.N.; Bruxner, T.J.; Quinn, M.C.; et al. Genomic analyses identify molecular subtypes of pancreatic cancer. Nature 2016, 531, 47-52. [CrossRef]

195. Zhao, L.; Zhao, H.; Yan, H. Gene expression profiling of 1200 pancreatic ductal adenocarcinoma reveals novel subtypes. BMC Cancer 2018, 18, 603. [CrossRef] [PubMed]

196. Lomberk, G.; Blum, Y.; Nicolle, R.; Nair, A.; Gaonkar, K.S.; Marisa, L.; Mathison, A.; Sun, Z.; Yan, H.; Elarouci, N.; et al. Distinct epigenetic landscapes underlie the pathobiology of pancreatic cancer subtypes. Nat. Commun. 2018, 9, 1978. [CrossRef]

197. Maurer, C.; Holmstrom, S.R.; He, J.; Laise, P.; Su, T.; Ahmed, A.; Hibshoosh, H.; Chabot, J.A.; Oberstein, P.E.; Sepulveda, A.R.; et al. Experimental microdissection enables functional harmonisation of pancreatic cancer subtypes. Gut 2019, 68, 1034-1043. [CrossRef] [PubMed]

198. Dijk, F.; Veenstra, V.L.; Soer, E.C.; Dings, M.P.G.; Zhao, L.; Halfwerk, J.B.; Hooijer, G.K.; Damhofer, H.; Marzano, M.; Steins, A.; et al. Unsupervised class discovery in pancreatic ductal adenocarcinoma reveals cell-intrinsic mesenchymal features and high concordance between existing classification systems. Sci. Rep. 2020, 10, 337. [CrossRef]

199. Chan-Seng-Yue, M.; Kim, J.C.; Wilson, G.W.; Ng, K.; Figueroa, E.F.; O’Kane, G.M.; Connor, A.A.; Denroche, R.E.; Grant, R.C.; McLeod, J.; et al. Transcription phenotypes of pancreatic cancer are driven by genomic events during tumor evolution. Nat. Genet. 2020, 52, 231-240. [CrossRef] [PubMed]

200. Juiz, N.; Elkaoutari, A.; Bigonnet, M.; Gayet, O.; Roques, J.; Nicolle, R.; Iovanna, J.; Dusetti, N. Basal-like and classical cells coexist in pancreatic cancer revealed by single-cell analysis on biopsy-derived pancreatic cancer organoids from the classical subtype. FASEB J. 2020, 34, 12214-12228. [CrossRef]

201. Bilzer, M.; Roggel, F.; Gerbes, A.L. Role of Kupffer cells in host defense and liver disease. Liver Int. 2006, 26, 1175-1186. [CrossRef]

202. Wright, J.R. Clearance and recycling of pulmonary surfactant. Am. J. Physiol. 1990, 259, L1-L12. [CrossRef] [PubMed]

203. Purnama, C.; Ng, S.L.; Tetlak, P.; Setiagani, Y.A.; Kandasamy, M.; Baalasubramanian, S.; Karjalainen, K.; Ruedl, C. Transient ablation of alveolar macrophages leads to massive pathology of influenza infection without affecting cellular adaptive immunity. Eur. J. Immunol. 2014, 44, 2003-2012. [CrossRef]

204. Lee, B.; Qiao, L.; Kinney, B.; Feng, G.S.; Shao, J. Macrophage depletion disrupts immune balance and energy homeostasis. PLoS ONE 2014, 9, e99575. [CrossRef] [PubMed]

205. Kumar, V.; Donthireddy, L.; Marvel, D.; Condamine, T.; Wang, F.; Lavilla-Alonso, S.; Hashimoto, A.; Vonteddu, P.; Behera, R.; Goins, M.A.; et al. Cancer-Associated Fibroblasts Neutralize the Anti-tumor Effect of CSF1 Receptor Blockade by Inducing PMN-MDSC Infiltration of Tumors. Cancer Cell 2017, 32, 654-668.e655. [CrossRef] [PubMed]

206. Li, M.; Li, M.; Yang, Y.; Liu, Y.; Xie, H.; Yu, Q.; Tian, L.; Tang, X.; Ren, K.; Li, J.; et al. Remodeling tumor immune microenvironment via targeted blockade of PI3K- $\gamma$ and CSF-1/CSF-1R pathways in tumor associated macrophages for pancreatic cancer therapy. J. Control Release 2020, 321, 23-35. [CrossRef]

207. Yang, Y.; Guo, J.; Huang, L. Tackling TAMs for Cancer Immunotherapy: It's Nano Time. Trends Pharmacol. Sci. 2020, 41, 701-714. [CrossRef]

208. Babicky, M.L.; Harper, M.M.; Chakedis, J.; Cazes, A.; Mose, E.S.; Jaquish, D.V.; French, R.P.; Childers, B.; Alakus, H.; Schmid, M.C.; et al. MST1R kinase accelerates pancreatic cancer progression via effects on both epithelial cells and macrophages. Oncogene 2019, 38, 5599-5611. [CrossRef]

209. Yao, L.; Wang, M.; Niu, Z.; Liu, Q.; Gao, X.; Zhou, L.; Liao, Q.; Zhao, Y. Interleukin-27 inhibits malignant behaviors of pancreatic cancer cells by targeting M2 polarized tumor associated macrophages. Cytokine 2017, 89, 194-200. [CrossRef]

210. Cassier, P.A.; Garin, G.; Eberst, L.; Delord, J.-P.; Chabaud, S.; Terret, C.; Montane, L.; Bidaux, A.-S.; Laurent, S.; Jaubert, L.; et al. MEDIPLEX: A phase 1 study of durvalumab (D) combined with pexidartinib (P) in patients (pts) with advanced pancreatic ductal adenocarcinoma (PDAC) and colorectal cancer (CRC). J. Clin. Oncol. 2019, 37, 2579. [CrossRef]

211. Harb, W.A.; Johnson, M.L.; Goldman, J.W.; Weise, A.M.; Call, J.A.; Dudek, A.Z.; Gonzalez, R.; Cowey, C.L.; Eves, P.T.; Gollerkeri, A.; et al. A phase $1 \mathrm{~b} / 2$ study of ARRY-382, an oral inhibitor of colony stimulating factor 1 receptor (CSF1R), in combination with pembrolizumab (Pembro) for the treatment of patients (Pts) with advanced solid tumors. J. Clin. Oncol. 2017, 35, TPS3110. [CrossRef] 
212. Melisi, D.; Hollebecque, A.; Oh, D.-Y.; Calvo, E.; Varghese, A.M.; Borazanci, E.H.; Mercade, T.M.; Simionato, F.; Park, J.O.; Bendell, J.C.; et al. A phase $\mathrm{Ib}$ dose-escalation and cohort-expansion study of safety and activity of the transforming growth factor (TGF) $\beta$ receptor I kinase inhibitor galunisertib plus the anti-PD-L1 antibody durvalumab in metastatic pancreatic cancer. J. Clin. Oncol. 2019, 37, 4124. [CrossRef]

213. Chiorean, E.G.; Hochster, H.S.; Nanda, S.; Thornton, D.; Klise, S. A phase II study of abemaciclib as a monotherapy and in combination with other agents in patients with previously treated metastatic pancreatic ductal adenocarcinoma (PDAC). J. Clin. Oncol. 2017, 35, TPS4150. [CrossRef]

214. Tempero, M.; Oh, D.Y.; Tabernero, J.; Reni, M.; Van Cutsem, E.; Hendifar, A.; Waldschmidt, D.T.; Starling, N.; Bachet, J.B.; Chang, H.M.; et al. Ibrutinib in combination with nab-paclitaxel and gemcitabine for first-line treatment of patients with metastatic pancreatic adenocarcinoma: Phase III RESOLVE study. Ann. Oncol. 2021. [CrossRef] [PubMed]

215. Wang-Gillam, A.; O’Reilly, E.M.; Bendell, J.C.; Wainberg, Z.A.; Borazanci, E.H.; Bahary, N.; O’Hara, M.H.; Beatty, G.L.; Pant, S.; Cohen, D.J.; et al. A randomized phase II study of cabiralizumab (cabira) + nivolumab (nivo) \pm chemotherapy (chemo) in advanced pancreatic ductal adenocarcinoma (PDAC). J. Clin. Oncol. 2019, 37, TPS465. [CrossRef]

216. Calvo, A.; Joensuu, H.; Sebastian, M.; Naing, A.; Bang, Y.-J.; Martin, M.; Roda, D.; Hodi, F.S.; Veloso, A.; Mataraza, J.; et al. Phase $\mathrm{Ib} / \mathrm{II}$ study of lacnotuzumab (MCS110) combined with spartalizumab (PDR001) in patients (pts) with advanced tumors. J. Clin. Oncol. 2018, 36, 3014. [CrossRef]

217. Cohen, D.J.; Medina, B.; Du, K.L.; Coveler, A.L.; Manji, G.A.; Oberstein, P.E.; Perna, S.K.; Miller, G. Phase II multi-institutional study of nivolumab (Nivo), cabiralizumab (Cabira), and stereotactic body radiotherapy (SBRT) for locally advanced unresectable pancreatic cancer (LAUPC). J. Clin. Oncol. 2019, 37, TPS4163. [CrossRef]

218. Coveler, A.L.; Bajor, D.L.; Masood, A.; Yilmaz, E.; Shields, A.F.; Javle, M.M.; Paluri, R.K.; Vaccaro, G.M.; Zalupski, M.; GrilleyOlson, J.E.; et al. Phase I study of SEA-CD40, gemcitabine, nab-paclitaxel, and pembrolizumab in patients with metastatic pancreatic ductal adenocarcinoma (PDAC). J. Clin. Oncol. 2020, 38, TPS4671. [CrossRef] 